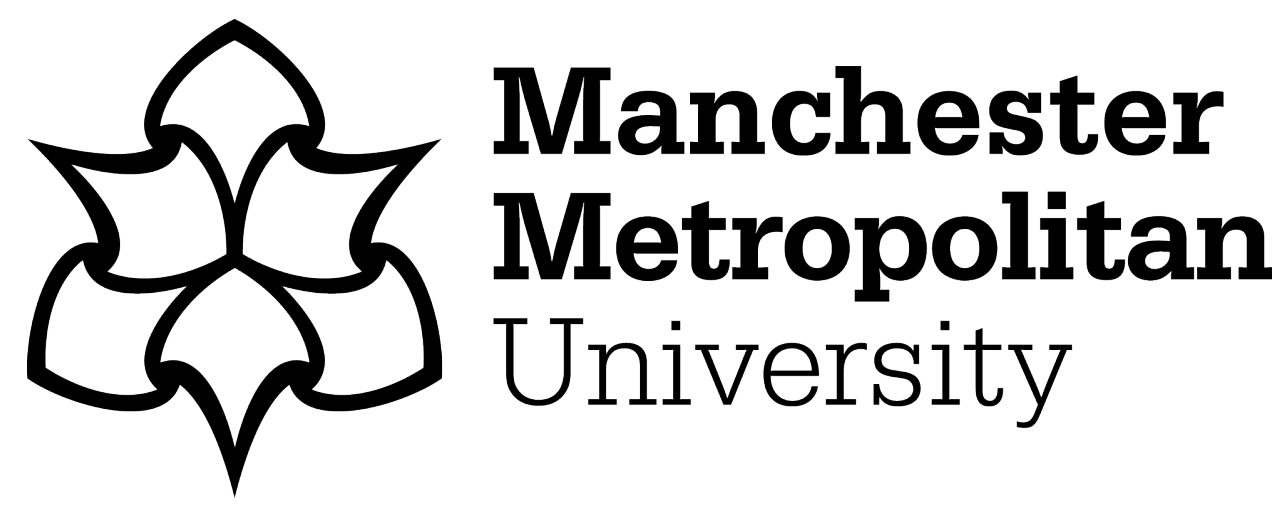

Williams, LR, Hiscott, RN, Aksu, AE, Bradley, Lee, Horne, DJ and Stoica, M (2018) Holocene paleoecology and paleoceanography of the southwestern Black Sea shelf revealed by ostracod assemblages. Marine Micropaleontology, 142. pp. 48-66. ISSN 0377-8398

Downloaded from: https://e-space.mmu.ac.uk/620845/

Version: Accepted Version

Publisher: Elsevier

DOI: https://doi.org/10.1016/j.marmicro.2018.06.001

Usage rights: Creative Commons: Attribution-Noncommercial-No Derivative Works 4.0

Please cite the published version 


\section{Accepted Manuscript}

Holocene paleoecology and paleoceanography of the southwestern Black Sea shelf revealed by ostracod assemblages

L.R. Williams, R.N. Hiscott, A.E. Aksu, L.R. Bradley, D.J. Horne, M. Stoica

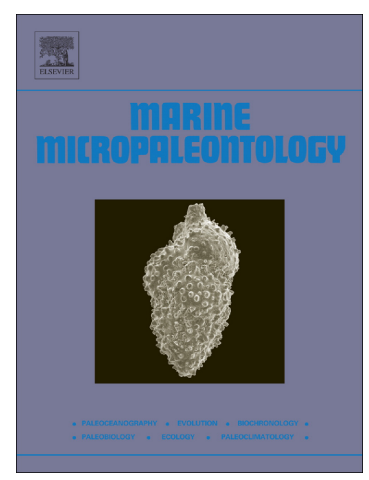

PII:

S0377-8398(18)30008-2

DOI: doi:10.1016/j.marmicro.2018.06.001

Reference: MARMIC 1699

To appear in: Marine Micropaleontology

Received date: 5 February 2018

Revised date: 24 May 2018

Accepted date:

2 June 2018

Please cite this article as: L.R. Williams, R.N. Hiscott, A.E. Aksu, L.R. Bradley, D.J. Horne, M. Stoica, Holocene paleoecology and paleoceanography of the southwestern Black Sea shelf revealed by ostracod assemblages. Marmic (2017), doi:10.1016/ j.marmicro.2018.06.001

This is a PDF file of an unedited manuscript that has been accepted for publication. As a service to our customers we are providing this early version of the manuscript. The manuscript will undergo copyediting, typesetting, and review of the resulting proof before it is published in its final form. Please note that during the production process errors may be discovered which could affect the content, and all legal disclaimers that apply to the journal pertain. 


\title{
Holocene paleoecology and paleoceanography of the southwestern Black Sea shelf revealed by ostracod assemblages
}

\author{
L.R. Williams ${ }^{1}$ *, R.N. Hiscott ${ }^{1}$, A.E. Aksu ${ }^{1}$, L.R. Bradley ${ }^{2}$, D.J. Horne ${ }^{3}$, M. Stoica ${ }^{4}$
}

1 Earth Sciences Department, Memorial University of Newfoundland, St. John's, NL, A1B 3X5, Canada

2 School of Science and the Environment, Manchester Metropolitan University, Manchester, M1 5GD, United Kingdom

3 School of Geography, Queen Mary University of London, Mile End Road, London E1 4NS, United Kingdom

4 University of Bucharest, Bucharest, Faculty of Geology and Geophysics, Bucharest, District 5, Romania

*Corresponding author

e-mail: lorna.williams@fugro.com (L.R.Williams)

e-mail: rhiscott@mun.ca (R.N. Hiscott)

e-mail: aaksu@mun.ca (A.E. Aksu)

e-mail: 1.bradley@mmu.ac.uk (L.R. Bradley)

e-mail: d.j.horne@qmul.ac.uk (D.J. Horne)

e-mail: marius.stoica@g.unibuc.ro (M. Stoica)

Telephone/Fax: 1709726 4252/1 7097265007 (LRW) 


\section{Abstract}

The Holocene replacement of Ponto-Caspian ostracod assemblages by Mediterranean species is studied in two long composite cores, M02-45 (a composite of cores M02-45P, M0245T and M05-03P) and M05-50 (a composite of cores M05-50P and M05-51G), acquired at sites $-69 \mathrm{~m}$ and $-91 \mathrm{~m}$ deep on the southwestern Black Sea shelf. Composite core M02-45 was collected from the middle shelf and composite core M05-50 was acquired on the distal fringe of the eastern levée of a saline underflow channel emanating from the Strait of Bosphorus. Sixteen radiocarbon dates in M02-45 and nine in M05-50 are used to construct age models, which show recovery of sediments as old as 12915 cal yr BP (M02-45 site) and 12010 cal yr BP (M05-50 site). A total of 45 ostracod species are identified in the two cores. From $\sim 12000$ to $\sim 7425$ cal yr BP, the ostracod assemblage is dominated by Ponto-Caspian species, mainly Loxoconcha sublepida, L. lepida and Tyrrhenocythere amnicola donetziensis. From 7425 to $\sim 6315 \mathrm{cal} \mathrm{yr}$ BP the assemblage consists of nearly equal abundances of Mediterranean species (Cytheroma variabilis in M02-45; Sagmatocythere littoralis in M05-50) and the Ponto-Caspian species. After $\sim 6315 \mathrm{cal} \mathrm{yr}$ BP to the tops of the cores, the assemblage is dominated by Mediterranean species, including Palmoconcha agilis, Carinocythereis carinata, Hiltermannicythere rubra and Pterygocythereis jonesii. Cluster analysis further subdivides the stratigraphic succession into six bioecozones with different ostracod assemblages. The changes in the ostracod assemblages from one bioecozone to the next indicate that progressive environmental changes took place on the southwestern Black Sea shelf from at least 7500 cal yr BP to the present. The first hint of changing conditions at $\sim 7500$ cal yr BP lags the initial reconnection to the Mediterranean Sea through the Strait of Bosphorus by 2000 yr, demonstrating that Black Sea salinity increased slowly and took that long to reach values tolerable to marine ostracod immigrants. Widespread 
colonization by Mediterranean species took even longer, $~ 3000$ years from the time of the initial reconnection.

Key words: Ostracods, Black Sea, salination, environmental change, Holocene paleoecology, ecological watermasses 


\section{Introduction}

The Black Sea is the largest permanently anoxic basin in the world (Murray and İzdar, 1989), situated between the Pontic Mountains of northern Turkey to the south, the Caucasus and Crimea Mountains of Russia and Ukraine to the north and northeast, and the Danube, Dneister, Dneiper and Bug alluvial plains to the west and northwest (Fig. 1). It is connected to the Aegean Sea and the eastern Mediterranean Sea through the Strait of Bosphorus, the landlocked Marmara Sea and the Strait of Dardanelles, collectively referred to as the Marmara Sea Gateway. A twoway flow exists between the Mediterranean Sea, Aegean Sea and Black Sea via the Marmara Sea Gateway (Latif et al., 1992). The Black Sea watermass consists of a low-salinity (17-20 practical salinity units (psu), hereafter unitless) 25-100 m-thick surface layer which flows at a velocity of $10-30 \mathrm{~cm} \mathrm{~s}^{-1}$ into the northern Aegean Sea. Higher salinity (38-39) warm (15-20 $\left.{ }^{\circ} \mathrm{C}\right)$ Mediterranean water flows north and east across the gateway eventually entering the Black Sea where it contributes to a bottom watermass below the low-salinity, low-density surface water layer (Özsoy et al., 1995). At the northern Bosphorus exit, the underflow salinity is $\sim 35$ and at the shelf edge it is reduced to $\sim 31$ by entrainment of surface water (Özsoy et al., 2001). A prominent submarine channel begins at the Bosphorus exit and extends to the shelf edge northwest of the Bosphorus Canyon, accommodating the inflow of Mediterranean bottom water into the Black Sea (Fig. 2; Flood et al., 2009; Hiscott et al., 2013).

The Black Sea water column exhibits strong vertical stratification and there is little mixing between the bottom water layer and the upper oxygen-rich layer (i.e., a meromictic water body) because the intervening 50-200 m-deep halocline is deeper than the storm wave base. The warmer, higher-salinity, higher-density bottom water layer below a depth of 150-200 m is 
permanently anoxic and enriched in hydrogen sulfide (Panin and Strechie, 2006; Eckert et al., 2013).

The Holocene connection history of the Black Sea to the eastern Mediterranean Sea has been vigorously debated, as summarized in Ryan et al. (2003), Hiscott et al. (2007a), YankoHombach et al. (2007) and Yanchilina et al. (2017). Remaining disagreements can be understood by comparing Yanchilina et al. (2017), who advocate an abrupt incursion of saline water into a lowstand Black Sea taking a few decades to raise its level from -120 m relative to modern sea level (rmsl) to -30 m rmsl, to studies by Lister et al. (2015), Aksu et al. (2016) and Hiscott et al. (2017) which assert that the Black Sea was already approaching a highstand and was flowing out into the Marmara Sea and beyond by the earliest Holocene, so that the first input of saline water advanced northward as a salt wedge and underflow through the Strait of Bosphorus, beneath the outflow, leading to a progressive and slow salination.

\section{Methods}

Several piston and gravity cores were collected from the southwestern Black Sea shelf using the RV Koca Piri Reis of Dokuz Eylül University (Figs. 1, 2). The piston-coring equipment consisted of a Mooring Systems Inc. ${ }^{\text {TM }}$ Kullenburg-type piston corer (original Benthos $^{\mathrm{TM}}$ design) with split piston option, $1000 \mathrm{~kg}$ head, and $\sim 4.5 \mathrm{~m}$ free-fall. Five cores were selected for further detailed studies: piston cores M02-45P, M05-03P, M05-50P and gravity cores M02-45T and M05-51G. Two of these cores (M05-50P and M05-51G) are located on the outer fringe of the eastern levée of a saline underflow channel (Flood et al., 2009; Hiscott et al., 2013), while three cores (M02-45P, M02-45T and M05-03P) are located on the middle shelf, $\sim 66 \mathrm{~km}$ northwest of the saline channel near the Turkish-Bulgarian border. Cores M02-45T and M02-45P are trigger-weight and piston cores acquired $<1 \mathrm{~m}$ apart during the same deployment. 
Cores M02-45P/T and M05-03P penetrated the seabed 500 m apart, while cores M05-50P and M05-51G penetrated the seabed $\sim 310 \mathrm{~m}$ apart (Figs. 3, 4). On the basis of visual core descriptions and carbon and sulfur elemental and isotopic data, a $50 \mathrm{~cm}$ core-top loss is calculated for M05-50P relative to M05-51G (Linegar, 2012). A composite core for this site (hereafter designated as M05-50) was created by adding data for the upper $50 \mathrm{~cm}$ of core M05$51 \mathrm{G}$ to the top of core M05-50P. A similar exercise showed a $110 \mathrm{~cm}$ core-top loss for M02-45P relative to the co-located M02-45T (Hiscott et al., 2007b). During a later campaign, piston core M05-03P was acquired in an effort to extend recovery downward to the $\alpha$ unconformity (Fig. 3). Precise matching of elemental and isotopic trends for M02-45P/T with those for M05-03P, and radiocarbon dates, allows correlation of all three cores to within $<5 \mathrm{~cm}$ uncertainty (Fig. 5; Reynolds, 2012). This correlation indicates that M05-03P recovered an estimated $78 \mathrm{~cm}$ of sediments older than the base of core M02-45P. In this paper, data from the basal $78 \mathrm{~cm}$ of core M05-03P are added to data from the M02-45P/T pair to form what is hereafter referred to as the M02-45 composite.

Approximately $20-25 \mathrm{~cm}^{3}$ of sediment were taken from cores M05-50P and M05-51G at $10 \mathrm{~cm}$ intervals to complete the M05-50 composite. Cores M02-45P and M02-45T were sampled at less regular intervals to fill the gaps in an earlier study of the same cores by Evans (2004; discussed later). Finally, the lowermost $70 \mathrm{~cm}$ of M05-03P was sampled at $10 \mathrm{~cm}$ intervals to complete the M02-45 composite. The samples were first oven-dried at $\sim 25^{\circ} \mathrm{C}$ and the dry weights were recorded. They were then put into small plastic containers and treated with $\sim 70 \mathrm{ml}$ of $1 \%$ Calgon solution and left for several days, gently shaken occasionally to disaggregate the sediments. Each sample was wet-sieved using a $63 \mu \mathrm{m}$ sieve. To prevent contamination, the sieve was carefully washed, dried front and back with pressurized air, and 
visually inspected to remove adhering grains between successive samples. The $>63 \mu \mathrm{m}$ fractions were collected, dried in an oven at $\sim 25^{\circ} \mathrm{C}$, then passed through a stack of four sieves $(355 \mu \mathrm{m}$, $180 \mu \mathrm{m}, 125 \mu \mathrm{m}$ and $63 \mu \mathrm{m})$ to separate the sample into smaller more manageable portions for subsequent hand-picking of ostracod valves and carapaces.

Each sample was examined under a stereoscopic microscope. Ostracod valves were hand-picked using a size 000 paint brush wetted with water. All valves that could be found in the samples were collected. Fragments were also collected; however, fragments that were less than $\sim 30 \%$ of the original valve, or fragments inadequate for identification, were not picked. All instar stages (i.e., adults and juveniles) of the ostracods were also picked.

The ostracod valves are well-preserved throughout the cores. Because no internal softpart preservation was observed, the ostracods were identified based on gross morphology of the valves. Shell shape and size, surface ornamentation, types of marginal pore canals, and internal features including the hinge, muscle imprints, inner lamella, and vestibule are keys to identifying ostracod taxa. Examination of valve morphology was done mainly under a stereoscopic microscope. Transmitted light microscopy was also used to observe characteristics not discernible with a stereoscopic microscope, mainly marginal pore canals. Ostracods have nine growth stages: eight juvenile stages and one adult stage (Athersuch et al., 1989). Thus, one individual ostracod may contribute up to 18 valves to the sediment over its lifetime. It is impossible then to really know how many individuals are actually represented in a sample because it will usually contain disarticulated valves as well as articulated carapaces and probably various juvenile stages. In this study, one valve (i.e., half of a full carapace) is counted as 1, while a full carapace is counted as 2 (Boomer et al., 2003). The ecological affinities of the ostracods present in this study can be differentiated into freshwater, brackish and marine (Puri et 
al., 1964; Schornikov, 1964, 1966, 1969; Bonaduce et al., 1975; Athersuch et al., 1989; Stancheva, 1989; Boomer et al., 1996, 2005, 2010; Opreanu, 2008; Zenina et al., 2017).

\section{Stratigraphy and age models}

\subsection{Core Descriptions}

Composite core M05-50 consists mostly of Holocene sediments on the eastern bank of a submarine channel north of the Bosphorus exit (Figs. 2, 4). The original core descriptions were published by Flood et al. (2009). The composite core is $787 \mathrm{~cm}$ long (Fig. 6). Bioturbation is only moderate in core M05-50 and is not believed to affect ostracod distribution at the $10 \mathrm{~cm}$ vertical sample spacing used for this study. Three lithostratigraphic units are defined. Unit 3 extends from the base of the composite core to an unconformity at $695 \mathrm{~cm}$ depth which corresponds to the $\alpha 1$ reflector in high-resolution seismic data (Figs. 4, 6). This unit is comprised of interbedded silty mud and graded beds of coarse silt to mainly very fine sand. The brackish water bivalve Dreissena is abundant in some of the graded beds (Flood et al., 2009). Unit 2 extends from $695 \mathrm{~cm}$ to $95 \mathrm{~cm}$ and consists of moderately bioturbated silty mud $(\leq 10 \%$ sand) with scattered marine mollusc shells above a composite depth of $513 \mathrm{~cm}$. Unit 1 extends from $95 \mathrm{~cm}$ to the top of core M05-50 and is distinguished from Unit 2 by its color banding. The texture is silty mud.

Composite core M02-45 consists of Holocene sediments on the middle shelf $\sim 66 \mathrm{~km}$ northwest of the M05-50 site (Figs. 1, 3, 6). Water depth at the site is $-69 \mathrm{~m}$. Except for the lower $78 \mathrm{~cm}$, the original core descriptions were published by Hiscott et al. (2007b). The composite core M02-45 is $1028 \mathrm{~cm}$ long. Four lithologic units are recognized (Fig. 6); these are given alphabetical identifiers to distinguish them from the units in composite core M05-50. The oldest Unit D extends from the base of the core to $970 \mathrm{~cm}$ composite depth. The base of the unit 
correlates with the seismic reflector $\alpha$ (Figs. 3, 6). The lowermost $10 \mathrm{~cm}$ of Unit D consists of mud containing scattered pebbles and cobbles, and is succeeded by alternating horizons of sandy mud, shell hash and very coarse sand and gravel. Unit C extends from $970 \mathrm{~cm}$ to a composite depth of $480 \mathrm{~cm}$. Its top therefore correlates to seismic reflector $\alpha 1$ (Fig. 3). Unit C consists of color-banded mud with graded laminae and beds of silt to very fine sand (Fig. 6), and scattered shells of Truncatella subcylindrica, Monodacna pontica, Didacna spp., Dreissena polymorpha and D. rostriformis Hiscott et al. (2010). It was divided by Hiscott et al. (2007b) into subunit C1 below $615 \mathrm{~cm}$ and subunit $\mathrm{C} 2$ above that depth based on geochemistry. Unit B extends upward from $480 \mathrm{~cm}$ to $270 \mathrm{~cm}$, the latter just below a $<5 \mathrm{~cm}$-thick shelly horizon which correlates in the seismic data to unconformity $\alpha 2$. Unit B consists of alternating horizons of mud and shelly mud (Fig. 6). The abundance of bioclastic sand locally exceeds $20 \%$. The mollusc assemblage includes T. subcylindrica, Mytilus galloprovincialis, Parvicardium exiguum, Rissoa spp. and Modiolula phaseolina (Hiscott et al., 2007b). Unit A represents the youngest sediments in the composite core. It consists of color-mottled/banded, burrowed mud with silt laminae and scattered shells of several immigrant Mediterranean molluscs: Bittium reticulatum, Spisula subtruncata, Acanthocardia paucicostata, Abra alba, M. galloprovincialis, T. subcylindrica, and Turritella communis.

\subsection{Radiocarbon dates and age model}

A total of 33 radiocarbon ages were obtained from composite cores M05-50 (13 dates) and M02-45 (20 dates) (Table 1). Eight and thirteen of the uncalibrated dates from M05-50 and M02-45 were originally published by Flood et al. (2009) and Hiscott et al. (2007b), respectively. Transposing the stratigraphic record into a chronological framework requires the conversion of the raw radiocarbon dates (reported here with the units ${ }^{14} \mathrm{C}$ yr BP) to the astronomical timescale 
(with units of calendar years BP, or cal yr BP). For this task, we used the Marine13 calibration curve (Reimer et al., 2013) and estimates of the age of the contemporary inorganic carbon reservoir from which biogenic carbonate was precipitated. The Marine13 curve incorporates a modelled, time-varying reservoir age $(R)$ of $\sim 400 \mathrm{yr}$, but adjustments $(\Delta R)$ are required based on the composition and history of the local watermass (controlled in part by residence times of carbonate and bicarbonate ions in deeper waters, and any hard-water effect through supply of old carbon by rivers). Reservoir age is defined (Stuiver and Braziunas, 1993) as the difference in radiocarbon age between (a) marine precipitates (e.g., shells) or organic matter and (b) contemporaneous terrestrial organic material (e.g., wood) or precipitates (e.g., speleothems) that formed in contact with the atmosphere. The reservoir age of the modern Black Sea is $\sim 415 \mathrm{yr}$ (Siani et al., 2000), but appropriate reservoir ages prior to reconnection with the global ocean are controversial.

Kwiecien et al. (2008) and Soulet et al. (2011) advocated applying a time-varying reservoir age in the range $0-300{ }^{14} \mathrm{C}$ yr to pre-reconnection radiocarbon dates of Black Sea shells back to $\sim 12.0{ }^{14} \mathrm{C}$ ka (Fig. 7). Mudie et al. (2014) warned that the pre-reconnection reservoir age might have been, at times, $>1120{ }^{14} \mathrm{C}$ yr, but could not be firm on this assessment because of the possibility that a D. polymorpha shell in their study was reworked. Yanchilina et al. (2017) departed in a significant way from these earlier studies by arguing that the time-varying record of the Black Sea reservoir age could be determined by tuning (a) the $\delta^{13} \mathrm{C}$ and $\delta^{18} \mathrm{O}$ stable isotopic records for radiocarbon-dated shells secreted in the Black Sea to (b) the U/Th-dated stable isotopic records from stalagmites of the Sofular Cave, located immediately inland of the southern Black Sea coast. This novel approach is based on an expectation that carbon and oxygen incorporated into the cave dripstones would inherit their isotopic signatures from regional 
vegetation patterns (distribution of $\mathrm{C}_{3}$ versus $\mathrm{C}_{4}$ plants) and from water vapour in equilibrium with the surface waters of the adjacent sea. Yanchilina et al. (2017) provide supplementary data and graphs to support their preferred best match between the Black Sea and the Sofular Cave $\delta^{13} \mathrm{C}$ and $\delta^{18} \mathrm{O}$ records. The graphs (their supplementary file mmc5.pdf) employ scales of uncorrected (raw) ${ }^{14} \mathrm{C}$ ages for shells and calendar ages for the cave deposits, making it difficult to judge how application of time-varying reservoir ages might compensate for mismatches of key features in the graphs.

The validity of the Yanchilina et al. (2017) tuning is critical to the development of any late Quaternary age model (e.g., for core M05-50) because the rapid changes in reservoir age which they advocate effectively stretch or compress the resultant time scale. The large excursions and rapid changes in reservoir age proposed by those authors were independently assessed by replotting their supplementary data for carbon and oxygen isotopes (Fig. 8). The U/Th age for each Sofular Cave data point was converted to an equivalent atmospheric radiocarbon date using the definition table for the IntCal13 calibration curve (Reimer et al., 2013). The isotopic values for the Sofular Cave stalagmites were plotted against these atmospheric ${ }^{14} \mathrm{C}$ ages. Isotopic values for Black Sea molluscs were then superimposed, first as plots against uncorrected ${ }^{14} \mathrm{C}$ dates for each shell (Fig. 8 a,b), second after subtracting Yanchilina et al. (2017) $R$ values (Fig. 8 c,d) and third after subtracting $R$ values similar to those used by authors AEA and RNH in earlier work (e.g., Bradley et al., 2012; Mertens et al., 2012) (Fig. 8 e,f). For ${ }^{14} \mathrm{C}$ dates of $~ 9500-12000{ }^{14} \mathrm{C}$ yr BP, reservoir ages preferred here (Fig. 7) are similar to those proposed by Yanchilina et al. (2017) because of the need to match the prominent trough in $\delta^{13} \mathrm{C}$ values in the $\mathrm{B} \varnothing 1$ ling/Allerød warm interval. However, in the critical period surrounding the reconnection of the Black Sea to the global ocean, reservoir ages proposed by Yanchilina et 
al. (2017) do not provide a better match to the Sofular Cave data than author-preferred values, largely because the considerable scatter in both data sets does not allow unambiguous ties between (a) peaks, troughs or inflections in the marine data set and (b) features in the cave records. In the absence of truly compelling justification for the large swings in reservoir age proposed by Yanchilina et al. (2017), we have elected to undertake calibration of radiocarbon dates using a gradual increase in $R$ from its pre-reconnection minimum of $\sim 50{ }^{14} \mathrm{C}$ yr at $\sim 10200$ ${ }^{14} \mathrm{C}$ yr BP to reach $19^{\text {th }}-20^{\text {th }}$ century values (Siani et al., 2000) by the time euryhaline molluscs populated the Black Sea shelves $\left(\sim 7100{ }^{14} \mathrm{C}\right.$ yr BP according to Ryan et al., 2003; Hiscott et al., 2007b). $R$ values for dates in the range $8400-9400{ }^{14} \mathrm{C}$ yr BP are lower than those employed by the authors in earlier calibrations (Bradley et al., 2012; Mertens et al., 2012). After $7100{ }^{14} \mathrm{C}$ yr $\mathrm{BP}$, we have used the default Marine13 calibration with a fixed $\Delta R$ value of +10 years.

Nine calibrated ages from cores M05-50P and M05-51G were used to construct an age model for the composite core M05-50 (Fig. 6). The age at the top of the core is assumed to be zero. The ages assigned to depths of 695 and $696 \mathrm{~cm}$ were extrapolated using constant sedimentation rates between dated intervals to either side of the $\alpha 1$ unconformity. The $\alpha 1$ surface occurs between 695 and $696 \mathrm{~cm}$; the conformable surface $\alpha 2$ occurs at $~ 595 \mathrm{~cm}$ depth in the composite core (Fig. 6). Ignoring the $\alpha 1$ hiatus, the average sedimentation rate determined from the age model is $82 \mathrm{~cm} \mathrm{ka}^{-1}$. For samples spaced each $10 \mathrm{~cm}$, temporal resolution is $\sim 240 \mathrm{yr}$ since 2000 cal yr BP, 60-200 yr from 2000-4500 cal yr BP, then $\sim 125-140$ yr for the older parts of the cored succession. The $\alpha 1$ hiatus has a duration of 2200-2700 years depending on how the rather large \pm uncertainties for deeper ages (Table 1) are combined to guide the upward extrapolation to $696 \mathrm{~cm}$ composite depth. It is noteworthy that tracing of seismic reflections just below $\alpha 1$ in the vicinity of the M05-50 site indicates that as much as $\sim 1.3 \mathrm{~m}$ more section is 
present a short distance away, as the unconformity rises upward. The temporal resolution of 125-140 yr translates to an accumulation rate below $\alpha 1$ of $\sim 75 \mathrm{~cm} / 10^{3} \mathrm{yr}$. Therefore, $1.3 \mathrm{~m}$ of sediment might indicate that $\alpha 1$ developed in this area after $~ 9050$ cal yr BP, rather than after $10755 \mathrm{cal}$ yr BP as estimated at the core site itself (Table 1).

Sixteen calibrated ages from composite core M02-45 were used to construct an age model (Fig. 6). The ages assigned to depths 270 and $271 \mathrm{~cm}$ (straddling unconformity $\alpha 2$ ) were extrapolated using constant sedimentation rates between dated intervals above and below that level, leading to the conclusion that the $\alpha 2$ hiatus has a duration of $\sim 3390$ years. The conformable surface $\alpha 1$ occurs at $\sim 480 \mathrm{~cm}$ depth in the composite core (Fig. 6) where the interpolated age is $7260 \mathrm{cal} \mathrm{yr} \mathrm{BP}$. For samples spaced each $10 \mathrm{~cm}$, temporal resolution is $\sim 120$ yr since $\sim 9100$ cal yr BP, $\sim 30-50$ yr from 10000-9100 cal yr BP, then $\sim 500 \mathrm{yr}$ for the older parts of the cored succession. The last value implies a very reduced accumulation rate close to the basal $\alpha$ unconformity.

\subsection{Implications of the $\alpha, \alpha 1$ and $\alpha 2$ unconformities}

The $\alpha$ unconformity truncates a wide range of older strata, including Eocene-Pliocene tilted and deformed strata (Aksu et al., 2002b). It is a relatively flat surface with strong reflectivity in seismic profiles. Where exposed (Flood et al., 2009, their figure 16) or cored, there is a layer of gravel and/or coquina. Sediments below $\alpha$ on the southwestern shelf are generally older than $30,000{ }^{14} \mathrm{C}$ yr BP (Fig. 9). Therefore, $\alpha$ is interpreted as a lowstand subaerial unconformity modified by the last post-glacial transgression. But, $\alpha 2$ has an entirely different interpretation. At the M02-45 site it overlies sediment as young as 5445 cal yr BP when the Black Sea was fully connected to the world ocean and stood at $\sim-5 \mathrm{~m}$ relative to modern sea level (rmsl; Lambeck et al., 2007). Hence, water depth at the M02-45 site was little 
different to today and $\alpha 2$ has to be a submarine erosional surface, probably created by strong along-shelf currents associated with the Rim Current in the Black Sea (Flood et al., 2009). The $\alpha 1$ surface is believed to have a similar origin to $\alpha 2$. It becomes a conformable surface (or imperceptible disconformity) near the M02-45 site and is underlain by sediment as young as $7260 \mathrm{cal}$ yr BP. As explained above, sediment underneath $\alpha 1$ might be as young as $9050 \mathrm{cal} \mathrm{yr}$ BP near the M05-50 site. The level of the Black Sea was -10 m rmsl at 7260 cal yr BP, and $23 \mathrm{~m} \mathrm{rmsl}$ at $9050 \mathrm{cal}$ yr BP (Lambeck et al., 2007), the latter several hundred years after entry of the first Mediterranean water into the Black Sea (Yanchilina et al., 2017). Hence almost the entire southwestern shelf was apparently under tens of meters of water during $\alpha 1$ development and it must also be a subaqueous unconformity (to local conformity). Furthermore, there is no evidence in split cores of subaerial exposure; e.g., rooting, desiccation cracks, caliche nodules, other pedogenic textures, or changing water content.

\section{Ostracod results}

Ostracods are abundant and well-preserved throughout composite cores M05-50 and M02-45, with a total of 45 ostracod species. In composite cores M05-50 and M02-45 all ostracods found in the samples were handpicked and counted (Fig. 10). The ostracod assemblages in the composite cores are described using key ostracod species (Table 2; Figs. 11, 12). Key species are considered to be those which are consistently abundant, occur in most samples through particular core intervals and are represented by both adults and several stages of juveniles (see below). They can therefore be assumed to have lived and died at the core site, as opposed to having been reworked or transported to the site, and are therefore more reliable for reconstructing ecological changes in the study area (De Deckker, 2002; Boomer et al., 2003). Taphonomic assessment using population age diagrams (Fig. 13) is a useful precursor to using 
ostracods to interpret paleoenvironments (De Deckker, 2002; Boomer et al., 2003). By plotting how many valves of a particular species are present, from adults down to the smallest juveniles, an assessment of the taphonomic history of the assemblage can be made (Boomer et al., 2003). The population age diagrams for core M05-50 show that all assemblages are autochthonous (Fig. 13). The presence of various stages of juveniles in most samples indicates a low to moderate energy system.

\subsection{Composite core M05-50}

Three temporally distinctive ostracod assemblages are delineated in core M05-50: PontoCaspian assemblage, transitional assemblage and Mediterranean assemblage.

\section{Ponto-Caspian (brackish) assemblage $(780-630 \mathrm{~cm})$}

Samples from 780-630 cm depth in core M05-50 contain on average $96.9 \%$ specimens commonly found in brackish waters of the Ponto-Caspian basins (Fig. 14; e.g., Schornikov, 1969; Opreanu, 2008; Boomer et al., 2010). The brackish assemblage is overwhelmingly dominated by L. sublepida and L. lepida (Fig. 11, 12), in that these two species make up an average of $63.5 \%$ of each sample, with a maximum abundance of $81.5 \%$ at $660 \mathrm{~cm}$. Rare occurrences of $S$. littoralis are observed with abundances of $<2 \%$. The fact that these "flickering" occurrences are present for at least $1.5 \mathrm{~m}$ below the overlying $S$. littoralis peak rules out bioturbational mixing from higher levels, as does the lack of an upward increase in abundance that would be expected with bioturbation. If these rare occurrences were a coring artifact because of smearing of younger sediment along the core liners, then one should expect to see flickering occurrences of, for example, C. carinata and H. rubra, which are not recorded.

Other significant species in the Ponto-Caspian assemblage are T. amnicola donetziensis (averaging 11.2\%), Amnicythere olivia (5.4\%), Graviacypris elongate (4.9\%) and A. 
quinquetuberculata (4.3\%; Fig. 14). Species sporadically appearing in the brackish assemblage in low abundances of $<2 \%$ are Euxinocythere bacuana, Amnicythere pediformis, Amnicythere sp. aff. subcaspia, Amnicythere striatocostata, Amnicythere cymbula, Euxinocythere sp. aff. relicta, and Loxoconchissa (Loxocaspia) immodulata (Williams, 2012). The marine species Palmoconcha agilis (which is closely similar to the "granulata" form of P. guttata from the NW European coasts: the two might be considered synonymous) is present at most depths in the brackish section, but in extremely low abundances, typically only one or two valves per sample. Given the high abundances of this species in upper parts of the core (Fig. 14), contamination from mud smear along the core liner cannot be ruled out.

The $\alpha 1$ unconformity occurs within the brackish section at a depth of $695 \mathrm{~cm}$ in composite core M05-50 (Figs. 4, 14). It represents an 2500-year hiatus (averaging from 10725 to 8420 cal yr BP). The ostracod assemblage before and after this hiatus changes very little, but some differences are noteworthy: for example, L. sublepida and L. lepida increase from $55.6 \%$ to $70.0 \%$ from $730-700 \mathrm{~cm}$ depth ( 200 years preceding the hiatus $)$ to $690-670 \mathrm{~cm}$ depth $(\sim 250$ years after the hiatus; Fig. 14). Other changes over the same interval involve T. amnicola donetziensis which decreases from 18.9 to $5.6 \%$ and A. olivia which decreases from 7.4 to $2.6 \%$.

\section{Transitional assemblage $(620-540 \mathrm{~cm})$}

Samples from 620-540 cm depth show co-occurrence of brackish and marine ostracod species (Fig. 14). From $630 \mathrm{~cm}$ to $620 \mathrm{~cm}$ depth in the core the Mediterranean species $S$. littoralis (Fig. 9) dramatically increases in abundance from $1.7 \%$ to $40.6 \%$, and within the transitional assemblage it maintains an average abundance of $41.6 \%$, making it the dominant species. 
Brackish water species remain abundant in the transitional section (Fig. 14). Loxoconcha sublepida and L. lepida, which had been the dominant species in the brackish assemblage, become the second most abundant species in the transitional assemblage with an average abundance of $33.3 \%$. Likewise, T. amnicola donetziensis, which had been the second most abundant species in the brackish section, is still present in the transitional assemblage but its average abundance decreases from $11.2 \%$ to $5.8 \%$ as a result of dilution by S. littoralis, making T. amnicola donetziensis the third most abundant species.

The number of brackish species is still greater than the number of marine species. However, given the high number of specimens of the Mediterranean species S. littoralis, the average ratio of marine to brackish specimens is calculated to be 60:40 in the transitional section. In the earliest stages of the transitional section the Mediterranean species C. carinata, H. rubra and $C$. variabilis first appear albeit only a few individuals in core M05-50. The marine species $P$. agilis maintains a low percentage $(2.7 \%)$ in the transitional assemblage.

\section{Mediterranean (marine) assemblage $(530-0 \mathrm{~cm})$}

At $530 \mathrm{~cm}$ depth in core M05-50, the Mediterranean species S. littoralis decreases dramatically from $55.4 \%$ abundance at $540 \mathrm{~cm}$ depth to only $2.5 \%$ at $530 \mathrm{~cm}$ depth. Between the same two sample depths, the Ponto-Caspian species L. sublepida and L. lepida together decrease from $28.4 \%$ to $3.1 \%$. Above this depth, all Ponto-Caspian species are supplanted by the Mediterranean ostracods $P$. agilis, $H$. rubra, and C. carinata together constituting $89.4 \%$ of the $530 \mathrm{~cm}$ sample (Fig. 14). Together with other marine ostracods, these marine species dominate (at 99.2\%) the ostracod assemblage from that point upward to the top of the core. Sagmatocythere littoralis all but disappears in the marine assemblage, occurring only a few times represented by a valve or two. Loxoconcha sublepida and L. lepida do occur often in the marine 
assemblage but in extremely low abundances of $<1 \%$, and mainly below a depth of $250 \mathrm{~cm}$ (Fig. 14). These could be reworked. Tyrrhenocythere amnicola donetziensis also occurs in the marine assemblage in abundances typically $1 \%$ or less and most frequently between the depths $440 \mathrm{~cm}$ and $320 \mathrm{~cm}$. By far the most abundant taxon in the entire marine assemblage is the Mediterranean species $P$. agilis (Fig. 14). Valves of this species make up an average of $56.6 \%$ of each sample from $530 \mathrm{~cm}$ upward. The other significant species present in the marine assemblage of core M05-50 are Costa edwardsi and P. jonesii, with smaller abundances of Paracypris polita, Leptocythere multipunctata, Callistocythere diffusa, C. variabilis, Bythocythere sp. and Xestoleberis sp. aff. cornelii (Fig. 14).

\subsection{Composite core M02-45}

There are several fundamental similarities and some differences between the assemblages in core M02-45 when compared to M05-50. A portion of core M02-45 was initially studied at 20 cm sampling intervals by Evans (2004) with preliminary results briefly summarized in Hiscott et al. (2007b). Although most of the ostracod species identified in core M05-50 are also present in core M02-45, some notable differences exist: for example C. edwardsi, P. jonesii, and P. polita are three Mediterranean species in the marine Mediterranean assemblage in core M05-50 which are not recorded in core M02-45. Furthermore, S. littoralis occurs in core M02-45 in only very low abundances in three widely spaced samples (Evans, 2004). In core M05-50, S. littoralis has a much more significant role essentially dominating the entire transitional assemblage. Despite these differences, three temporally distinctive ostracod assemblages similar in their implications to those identified in core M05-50 are present in core M02-45: a Ponto-Caspian assemblage, transitional assemblage and Mediterranean assemblage. 


\section{Ponto-Caspian (brackish) assemblage (1012-490 cm)}

Samples from 1012-490 cm depth in core M02-45 contain on average 95.5\% brackishwater Ponto-Caspian species (Fig. 15). In the lowermost 30-35 cm of the composite core ( 975-1012 cm; lithologic Unit D) the brackish water assemblage is overwhelmingly dominated by T. amnicola donetziensis, averaging $48.1 \%$, with notable contributions from L. (Loxocaspia) immodulata, L. sublepida and L. lepida, and A. olivia (Fig. 15). The middle portion of the assemblage between 975 and $700 \mathrm{~cm}$ depth in the core has a diverse Ponto-Caspian assemblage dominated by G. elongata, L. sublepida and L. lepida with notable contributions from A. olivia, A. quinquetuberculata, E. bacuana and smaller influxes of A. striatocostata, Amnicythere sp. aff. subcaspia, Euxinocythere sp. aff. relicta and L. (Loxocaspia) immodulata (Fig. 15). The upper portion of the assemblage from $\sim 700 \mathrm{~cm}$ to $490 \mathrm{~cm}$ depth in the core is overwhelmingly dominated by L. sublepida and L. lepida and G. elongata, with minor contributions from A. olivia, A. quinquetuberculata and E. bacuana (Fig. 15).

\section{Transitional assemblage $(490-450 \mathrm{~cm})$}

In the five samples from 490-450 cm depth, brackish and marine ostracod species cooccur (Fig. 15). The fauna are characterized by large abundances of marine species of $C$. variabilis $(\sim 60 \%)$ with decreasing yet notable abundances of Ponto-Caspian species L. sublepida and L. lepida and minor occurrences of A. olivia, A. quinquetuberculata (Fig. 15). Palmoconcha agilis and $H$. rubra also occur within the zone, with progressively upward increasing abundances. The most striking characteristic of the assemblage is the co-occurrence of a few key Mediterranean and Ponto-Caspian species. The transitional assemblage is observed across a narrow depth zone of only $40 \mathrm{~cm}$, possibly raising the question: is this zone real or is it created by contamination? The high percentage of $C$. variabilis in sediment with $\sim 10 \%$ L. sublepida and 
L. lepida cannot be explained by downward smearing of $C$. variabilis from higher levels. It is possible that L. sublepida and L. lepida could be reworked or burrow-mixed into younger sediment from depths of $>490 \mathrm{~cm}$, but in that case why not other brackish ostracod species, such as A. quinquetuberculata and G. elongata to the same extent? Coring-induced contamination and bioturbational mixing can be ruled out because of the sharp downward disappearance of several marine species with effectively no "flickering" occurrences below, strongly suggesting that the transitional zone is indeed real.

\section{Mediterranean (marine) assemblage $(450-0 \mathrm{~cm})$}

Above $450 \mathrm{~cm}$ depth in core M02-45, a notable faunal turnover takes place where the brackish-water Ponto-Caspian ostracod assemblage is completely replaced by the Mediterranean ostracod assemblage (Fig. 15). Palmoconcha agilis and H. rubra show dramatic increases upcore with abundances collectively exceeding 80-85\%. The Ponto-Caspian species $L$. sublepida and L. lepida together decrease from $\sim 10 \%$ to $<1 \%$. By far the most abundant taxon in the marine assemblage is the Mediterranean species $P$. agilis with significant contributions from L. multipunctata, C. diffusa, C. variabilis, C. carinata and X. sp. aff. cornelii (Fig. 15). In comparison to the marine Mediterranean assemblage seen in core M05-50, there are several species which are notably absent, including $C$. edwardsi, P. jonesii, P. polita and S. littoralis (Fig. 14). This issue is discussed below.

\section{Cluster Analysis and bioecozones}

CONISS (Constrained Incremental Sums of Squares) cluster analysis (Grimm, 1987) was run on the age-converted ostracod data from composite cores M02-45 and M05-50 using Tilia software (Grimm, 2011). In each core, the results show six well-defined clusters (Figs. 16, 17; Table 3). These are called "bioecozones", consistent with the definition of Poag and Valentine 
(1976) that a bioecozone is "a body of strata characterized by a certain paleoenvironment that is inferred from its fossil content and that can be distinguished from the paleoenvironment of adjacent strata". A bioecozone may be time-transgressive.

\section{Bioecozone 1 - brackish water environment}

Bioecozone 1 is part of the lower brackish assemblage which occurs from the base of both composite cores M05-50 and M02-45 (Figs. 16, 17; Table 3). In cores M05-50 and M02-45 it is dated from 11910-10755 cal yr BP (truncated by unconformity $\alpha 1$ ), and 11780-9350 cal yr $\mathrm{BP}$, respectively. In both cores the most abundant species over these time intervals are $L$. sublepida and L. lepida, T. amnicola donetziensis, G. elongata, and A. quinquetuberculata (Figs. 16, 17; Table 3). These species and other less abundant ones such as E. bacuana, A. pediformis, A. cymbula and L. (Loxocaspia) immodulata (in core M02-45) are currently found living in the Caspian Sea which has a salinity range of 1-13. Graviacypris elongata prefers salinities of up to 8 (Aladin, 1993) and A. quinquetuberculata prefers salinities of up to 5 (Opreanu, 2008). Loxoconcha lepida is also found living in deltas around the Azov Sea where the maximum water depth is $14 \mathrm{~m}$ and salinity is very low, certainly far less than 10 at the coast. Amnicythere cymbula is found today in lagoons and estuaries in the Ponto-Caspian basins (Opreanu, 2008). On the basis of the upper salinity preferences of $G$. elongata, A. quinquetuberculata and $L$. lepida, Bioecozone 1 is interpreted to represent a low salinity environment, with salinities of $<10$, possibly as low as $5-8$.

\section{Bioecozone 2 - brackish water environment}

In composite core M05-50 the base of Bioecozone 2 cannot be assigned an age because sedimentation after the $\alpha 1$ hiatus did not begin until $\sim 8390$ cal yr BP. After the hiatus, Bioecozone 2 extends to $7450 \mathrm{cal} \mathrm{yr} \mathrm{BP} \mathrm{(Figs.} \mathrm{16,} \mathrm{17;} \mathrm{Table} \mathrm{3).} \mathrm{The} \alpha 1$ surface is conformable 
in composite core M02-45 (Hiscott et al., 2007b). There, Bioecozone 2 extends from 9350-7410 cal yr BP and is marked by notable upward changes in the ostracod fauna compared with Bioecozone 1. For example, T. amnicola donetziensis completely disappears, and Bioecozone 2 is dominated by G. elongata, L. lepida, and L. sublepida, with notable occurrences of other Ponto-Caspian species, including E. bacuana, A. olivia and A. quinquetuberculata (Fig. 17; Table 3). In the composite core M05-50 there are only small changes in this bioecozone relative to Bioecozone 1. Loxoconcha lepida together with L. sublepida together increase in abundance and T. amnicola donetziensis and A. olivia decrease in abundance (Table 3). The ostracod data suggest that the brackish environment persisted on the southwestern Black Sea shelf until $\sim 7425$ cal yr BP.

\section{Bioecozone 3 - transitional environment}

In both cores, Bioecozone 3 marks a major change in the ostracod assemblage (Figs. 16, 17; Table 3). In the composite core M02-45, this interval extends from 7410-6310 cal yr BP and is notably characterized by the influx of marine species $C$. variabilis with significant contributions from $P$. agilis and $H$. rubra and minor showings of L. multipunctata and $X$. sp. aff. cornelii (Figs. 17, 18; Table 3). In core M05-50 this interval begins with the first significant occurrence of marine ostracods (S. littoralis) at $\sim 7425$ cal yr BP and extends upward to the end of the co-occurrence of marine and brackish species at $\sim 6320$ cal yr BP (Figs. 17, 18). The change in the assemblage at the base of the bioecozone happens rather abruptly in geological terms, considering that it occurs within $10 \mathrm{~cm}$ of sediment representing $\sim 125-140$ years. If the species S. littoralis is truly stenohaline, as asserted by Ruggieri (1964) in studies near Naples, Italy, then it stands to reason that when the water reached precise conditions favored by $S$. littoralis this species was able to rapidly expand its population from only one or two specimens 
per sample in Bioecozone 1 to $40 \%$ in Bioecozone 3. Another possibility is that S. littoralis is simply an opportunistic species and was the fastest to colonize the new environment at the northern exit of the Bosphorus Strait, and took advantage of the lack of competition from others. Ivanova et al. (2007) regard this species as preferring salinities up to 18 so this might be an upper limit for the salinity around the core site toward the end of the Bioecozone 3 interval at $\sim 6320$ cal yr BP. However, even until this late date the brackish species L. sublepida, L. lepida and T. amnicola donetziensis also inhabited the site. The coexistence of brackish and marine species suggests that salinity was rising but remained toward the low end of the range preferred by the marine immigrants. Other marine ostracods, particularly $P$. agilis, were present in the later stages of the brackish interval along with S. littoralis (Fig. 16; Table 3). However, when the opportunity afforded by increasing salinity developed, S. littoralis was the first of the marine species to take advantage and colonize the area. It is possible that the salinity at that time was in the exact range suitable for S. littoralis to thrive. However, that particular salinity range was only sustained for $\sim 1000$ years after which other Mediterranean species began to replace $S$. littoralis.

Although the relative abundance of $S$. littoralis is lower at core site M02-45, the transitional interval is marked by Mediterranean species co-existing with lingering PontoCaspian brackish species for $\sim 1000$ years (Figs. 16-18). This observation supports the idea that the changes in water-mass characteristics and ecological parameters were protracted.

\section{Bioecozone 4 - earliest marine environment}

In composite core M05-50, Bioecozone 4 starts at $\sim 6320$ cal yr BP and marks the time when the brackish assemblage was completely displaced by marine species immigrating through the Strait of Bosphorus (Fig. 16; Table 3). The pioneering S. littoralis was rapidly replaced at 
this time by new Mediterranean species and the ostracod assemblage in the core became fully marine. The first ostracods to dominate the new marine assemblage in Bioecozone 4 were $P$. agilis, C. carinata and H. rubra (Fig. 16; Table 3). These species are found living today around the Mediterranean and adjoining seas where the salinities are 37-39. Palmoconcha agilis is found in the Adriatic Sea (Bonaduce et al., 1975) and it is abundant today around the shallow (10-100 m) shoreline of the Black Sea (Schornikov, 1967). Carinocythereis carinata can be found today all around the Atlantic Ocean and Mediterranean Sea and prefers depths of $\sim 60-80$ m (Keen, 1982; Athersuch et al., 1989). Hiltermannicythere rubra lives on the shallow banks around Ischia, Procida, Naples and the Sorrento Peninsula at depths up to $100 \mathrm{~m}$ (Puri et al., 1964).

In composite core M02-45, Bioecozone 4 begins at $\sim 6310$ cal yr BP, and is marked by a near complete disappearance of Ponto-Caspian brackish water species, and dominance by Mediterranean species (Fig. 17; Table 3). Cytheroma variabilis which dominated the transitional Bioecozone 3 is notably reduced in abundances while $P$. agilis becomes the dominant species with significant contributions from $H$. rubra and to a lesser extent $C$. diffusa. Lingering occurrence of G. elongata is found in one sample.

Bioecozone 4 is the earliest marine stage of the Holocene during which there was increasingly saline bottom water on the southwestern Black Sea shelf due to steady Mediterranean inflow. Salinity had risen to a point where it was unfavorable for brackish PontoCaspian species and they soon all but disappeared as Mediterranean ostracods began to diversify and flourish. 


\section{Bioecozone 5 - middle Holocene marine environment}

Bioecozone 5 is marked by a further increase in salinity indicated by the introduction of two new marine species in core M05-50 (Fig. 16). At $4310 \mathrm{cal}$ yr BP, C. edwardsi and P. jonesii both appear for the first time in core M05-50 and persist as two of the more common species in the marine assemblage. Pterygocythereis jonesii prefers salinities of 26-35 (Neale, 1988). Costa edwardsi and P. jonesii are both sublittoral species (Athersuch et al., 1989) and P. jonesii commonly occurs in water well over 80-100 m deep (Bonaduce et al., 1975; Penny, 1993). These two Mediterranean species are notably absent in composite core M02-45 (Fig. 17), where the fauna are dominated by $P$. agilis, but also show sustained occurrences of $H$. rubra, $C$. diffusa, C. variabilis, L. multipunctata, Leptocythere spp., and the first introduction of C. carinata (Fig. 17; Table 3). The base of Bioecozone 5 at the M02-45 site is younger than at the M05-50 site because of missing section at the $\alpha 2$ unconformity and so begins at $\sim 2055$ cal yr BP rather than at $4310 \mathrm{cal} \mathrm{yr} \mathrm{BP.}$

The Mediterranean species C. edwardsi, $P$. jonesii and $P$. polita prefer high salinities as indicated by their late arrival at core site M05-50 (Fig. 16). As with S. littoralis, these species are present at core site M05-50 but not at core site M02-45 simply due to the close proximity of the M05-50 site to the Strait of Bosphorus. A slightly lower salinity at core site M02-45 is not likely to be a contributing factor because these species were present at site M05-50 since $~ 4300$ cal yr BP (Fig. 17) when the salinity on the Black Sea shelf was lower than today (Mertens et al., 2012).

\section{Bioecozone 6 - late Holocene marine environment}

Bioecozone 6 started at $\sim 1590$ cal yr BP at core site M02-45 and $\sim 2390$ cal yr BP at core site M05-50 (Figs. 16-15; Table 3), so its base is more diachronous than for other bioecozones. 
Bottom water salinities across the southwestern Black Sea were probably very similar to modern values during Bioecozone 6 (see also Soulet et al., 2010). This bioecozone is defined by a decline in the marine species $P$. agilis and H. rubra which are common to Bioecozones 4 and 5. Palmoconcha agilis has an average abundance of $63.1 \%$ in Bioecozones 3 and 4 and in Bioecozone 6 it decreases to $42.6 \%$. There is also a major decline in L. multipunctata, X. sp. aff. cornelii and C. variabilis whose abundances all drop well below $1 \%$ in Bioecozone 6 . In core M05-50, $P$. jonesii and $C$. edwardsi become more abundant than previously and $P$. polita becomes much more common (Fig. 16; Table 3).

\section{Discussion}

The ostracod data obtained from composite cores M05-50 and M02-45 show that a distinct faunal turnover occurred from a brackish to a marine assemblage beginning at $~ 7400-$ 7450 cal yr BP (Figs. 16-18). In both cores, the suddenness of the onset of this turnover, occurring in $~ 150$ years, and its magnitude strongly suggest that it must have been driven by fundamental ecological changes at the core sites associated with the increasing salinity of the Black Sea following the reconnection to the Mediterranean Sea. The high faunal diversity (Evans, 2004; Williams 2012) excludes changes in oxygen availability as a cause of this turnover. Environmental preferences of the various taxa implicate climbing salinity as the primary control. It should be remembered that the turnover occurred almost $2000 \mathrm{yr}$ after strontium-isotopic evidence for the initial reconnection of the Black Sea with the Mediterranean Sea (Yanchilina et al., 2017), and when global sea level and Black Sea level were in tandem at $-12 \mathrm{~m}$ rmsl. Hence this rapid ecological event has nothing to do with the purported catastrophic flooding through the Strait of Bosphorus, but instead signals the attainment of a threshold beyond which marine ostracods could flourish and brackish-water ostracods became vulnerable. 
Other studies have demonstrated a significant lag in the salination of Black Sea surface waters relative to the time of first reconnection (e.g., Major et al., 2006; Hiscott et al., 2007b; Marret et al., 2009; Flood et al., 2009; Yanchilina et al., 2017). Hiscott et al. (2007b) and Marret et al. (2009) advocated that the first arrival of saline water was as short pulse(s) of Mediterranean inflow facilitated by a temporary weakening of Black Sea outflow and not the beginning of persistent two-way flow across the Strait of Bosphorus.

At the M05-50 site, sediments above the unconformity al provide evidence for the pace of post-glacial Mediterranean inflow into the Black Sea. Based on dinocyst data from core M0245, Hiscott et al. (2007b) suggested that after the initiation of persistent Mediterranean inflow, and the associated establishment of two-way exchanges across the Strait of Bosphorus, the salinity increased to $>10-12$. Such salinities would have been tolerable for the brackish-water ostracods in Bioecozone 2. Subsequently, the start of sulfate reduction signifying a good input of normal marine, saline water to the M02-45 site occurred at $\sim 8000$ cal $\mathrm{yr} \mathrm{BP}\left(7500{ }^{14} \mathrm{C} \mathrm{ka}\right.$ recalibrated from Hiscott et al., 2007b; also Mertens et al., 2012). This implies a lag of at least 500 years between the beginning of persistent marine inflow into the Black Sea at $\sim 8000$ cal yr $\mathrm{BP}$ and the pioneer colonization of the area by the first Mediterranean ostracod S. littoralis at 7450-7425 cal yr BP (Figs. 16-18). This lag is interpreted as the time needed for enough Mediterranean water to enter the Black Sea to raise the salinity to a level suitable for marine ostracods and to form a breeding population. This is in agreement with Major et al. (2006) who reinterpreted the date of $\sim 7570$ cal yr BP which Ryan et al. (1997) had initially thought marked initial Mediterranean inflow to instead mark the time when the salinity became suitable for Mediterranean molluscan fauna to begin colonizing the Black Sea. This lag in the progress of salination cannot be used to discriminate between a catastrophic versus a gradual initial 
reconnection, because modelling by Soulet et al. (2010) showed that even a very rapid rise in the level of the Black Sea from $\sim-90 \mathrm{~m}$ to $\sim-40 \mathrm{~m}$ due to the addition of $\sim 28000 \mathrm{~km}^{3}$ of 38 Mediterranean water would only increase the average salinity of a well mixed Black Sea by $\sim 2$.

Ostracod species found toward the base of cores M05-50 and M02-45 show that conditions in the Black Sea from $\sim 11910$ to $\sim 7425$ cal yr BP were brackish rather than fresh. Apart from the presence of the "Caspi-brackish" assemblage, the notable absence of typical freshwater lacustrine species (that are common and well-known in the European Holocene) is significant. A freshwater Black Sea lake has been postulated by Ryan et al. (1997), Soulet et al. (2010) and Yanchilina et al. (2017), but brackish conditions in the early Holocene Black Sea have been confirmed by a number of authors (Giunta et al., 2007; Mudie et al., 2007; Marret et al. ,2009; Mertens et al., 2012).

After the establishment at $\sim 8000$ cal yr BP of fully developed two-way flow through the Strait of Bosphorus, salinity values reached 13-14 during Bioecozone 3 time, followed by a 1416.5 climb through Bioecozone 4 time (Mertens et al., 2012). The 13-14 salinity was apparently tolerable for both marine and brackish water ostracods in the transitional Bioecozone 3. The M05-50 site is immediately adjacent to the saline underflow channel which crosses the shelf from the Strait of Bosphorus, so it is probable that the bottom waters after reconnection were more saline than 14 , even more conducive to marine ostracods.

The establishment of Bioecozone 4 at $\sim 6310-6320$ cal yr BP (Figs. 16-18) coincides approximately with the weakening of Black Sea outflow at $\sim 6400$ cal yr BP proposed by Hiscott et al. (2002), facilitating the entry of more marine water and organisms. The floor of the Strait of Bosphorus would have been continuously bathed with Mediterranean water; juvenile ostracods would have been more effectively transported by stronger northward-flowing bottom waters. 
This timing also coincides with the maximum input of organic carbon from marine sources at site M02-45 (Hiscott et al., 2007b) indicating a well-established reconnection.

At the start of Bioecozone 5 time, Mertens et al. (2012) indicate a sharp salinity rise to $\sim 17$ which then gradually climbs to $\sim 18$ after $\sim 2300$ cal yr BP. This is in agreement with the ostracod data from core M05-50 which show that salinity conditions reached near-modern levels in Bioecozone 6 starting at 2390 cal yr BP, which is $~ 5000$ years after the beginning of the Holocene faunal turnover at $\sim 7425$ cal yr BP.

The results of this study closely resemble the findings of Zenina et al. (2017), who studied Holocene environmental changes in the Black Sea using ostracod assemblages in two cores from its northeastern outer shelf. Those authors distinguished three distinctive faunal assemblages. Their assemblage $\mathrm{I}$ is characterized by a Caspian-type ostracod fauna with common occurrences of L. lepida and G. elongata and lesser quantities of L. sublepida (Zenina et al., 2017). This assemblage dominated the early Holocene up to $\sim 7.4$ cal ka BP. It is very similar both in composition and timing to bioecozones 1 and 2 identified at sites M02-45 and M05-50. The Zenina et al. (2017) assemblage II is characterized by a mixed fauna of Caspiantype species (e.g., L. lepida, L. sublepida and G. elongate) and Mediterranean-type species (e.g., H. rubra, L. multipunctata and P. agilis), co-existing from $\sim 7.4$ cal ka BP to 6.7 cal ka BP. Assemblage II is nearly identical in faunal characteristics and age to the transitional bioecozone 3 described in this study. Finally, the Zenina et al. (2017) assemblage III is characterized by the progressive dominance of Mediterranean species (particularly P. agilis, Bythocythere sp., and minor occurrences of $C$. carinata and C. diffusa) from 6.8 cal ka BP to the present.

The results of this study are also similar to the findings of Giunta et al. (2007) who noted three calcareous nannoplankton "ecozones" in sediment cores from the western Black Sea. They 
interpreted a gradual increase in salinity in the Black Sea after $\sim 7600$ cal yr BP. Based on changes in the calcareous nannoplankton Emiliania huxleyi and Braarudosphaera bigelowii they interpreted surface-water salinities of less than 11-17 prior to 7600 cal yr BP and >17 afterward until the onset of near-modern conditions by 3100 cal yr BP. Giunta et al. (2007) also noted that lithological boundaries always preceded biostratigraphic boundaries "probably because colonization of the new habitat by calcareous nannoplankton is gradual". We would generalize this statement to include the ostracod species examined in this study, as well as molluscs considered by other workers (e.g., Major et al., 2006).

The ostracod fauna show the presence of a diverse and thriving brackish-water ostracod community dominated by L. sublepida and L. lepida until $\sim 7425$ cal yr BP. Subsequently, the first Mediterranean species S. littoralis began to rapidly colonize the southwestern Black Sea shelf north of the Bosphorus Strait. For $\sim 900$ years the original Ponto-Caspian ostracod species and the new Mediterranean immigrant species lived at the M05-50 and M02-45 core sites in more-or-less equal abundances. After $\sim 6310$ cal yr BP the Mediterranean species began to diversify and dominate the core sites on the southwestern Black Sea shelf. The Ponto-Caspian ostracod species and the Mediterranean species $S$. littoralis were replaced by new Mediterranean ostracod species, the most abundant being $P$. agilis.

Two-way flow between the Black Sea and the Mediterranean Sea was initiated at $~ 8000$ cal yr BP, approximately 1500 years after strontium-isotopic evidence for first contact between the two watermasses. There was a further a lag of $\sim 500$ years between the first persistent entry of Mediterranean water into the Black Sea and the discernible colonization of the area by Mediterranean ostracod species. This lag is interpreted as the amount of time necessary for the water at the M05-50 core site to reach salinity levels favorable to ostracods migrating from the 
more saline environment of the Mediterranean Sea. Statistical analyses of the ostracod data show six bioecozones with distinct ostracod assemblages; changes in those assemblages indicate a gradual and sequential salination of the Black Sea bottom water as a result of steady inflow of Mediterranean waters. The uppermost Bioecozone 6 contains ostracods which prefer marine salinities, some of which can inhabit depths of $100 \mathrm{~m}$ or more, suggesting that sealevel and salinity in the Black Sea were near modern values by 2300 cal yr BP.

\section{Conclusions}

Ostracods are used to delineate the paleoceanographic and paleoecological evolution of the southwestern Black Sea in two composite cores (M02-45 and M05-50). Sixteen radiocarbon dates in M02-45 and nine in M05-50 constrain age models extending from 12900-12000 cal yr BP to the present. A local unconformity known as $\alpha 1$ occurs at $695 \mathrm{~cm}$ depth in core M05-50, corresponding to a hiatus of $~ 2200-2700$ years. This level is conformable in M02-45. Another local unconformity known as $\alpha 2$ occurs at $265 \mathrm{~cm}$ depth in core M02-45, corresponding to a hiatus of $\sim 3390$ years. This level is conformable in M05-50. The following are the salient results of the ostracod data:

- Ostracod valves collected from composite cores M05-50 (M05-50P \& M05-51G) and M02-45 (M02-45P/T \& M05-03P) reveal that from 11910-7425 cal yr BP the ostracod assemblage was dominated by brackish water Ponto-Caspian species. From 7425-6310 cal yr BP the Mediterranean species co-existed with brackish-water species in more-orless equal abundances. From 6310 cal yr BP to the present the Ponto-Caspian species were replaced by exclusively Mediterranean species.

- There was a time lag of $~ 500$ years between the initiation of persistent inflow from the Mediterranean Sea at $~ 8000$ cal yr BP (as part of a two-way flow system) and the 
colonization of the Black Sea shelf by the first Mediterranean ostracod species $S$. littoralis. This lag is interpreted as the time needed for enough water to enter the Black Sea to mix with the bottom water and raise the salinity to levels favourable to Mediterranean ostracod species.

- CONISS cluster analyses divided the cored succession into six bioecozones. Bioecozone 1 constitutes a lower, brackish assemblage dominated by L. sublepida, L. lepida, T. amnicola donetziensis, G. elongata, A. olivia and A. quinquetuberculata. Based on the modern occurrences of these species, the salinity of the Black Sea from 11910-7425 cal $\mathrm{yr} \mathrm{BP}$ is estimated to be $\sim 5-10$. Bioecozone 2 represents a transitional assemblage with salinities high enough for the Mediterranean species $S$. littoralis (and later others) to rapidly move into the area. S. littoralis might indicate that the salinity of the Black Sea bottom water from $\sim 7425-6310$ cal yr BP was $\sim 13-15$, with an upper limit of $\sim 18$ to account for the continued presence of several brackish-water species. Bioecozones 3, 4 and 5 are composed of marine assemblages.

\section{Acknowledgments}

We thank the officers and crew of the RV Koca Piri Reis for their assistance during the 2002, 2005, 2008 and 2011 geophysical and coring operations, particularly Dr. Doğan Yaşar for his continued support. We acknowledge the technical assistance of Dr. Roger Flood during the acquisition of the multibeam data in 2005, 2008 and 2011. We thank the Natural Sciences and Engineering Research Council of Canada (NSERC) for Shiptime and Discovery Grants to AEA and RNH. 


\section{References}

Aksu, A.E., Hiscott, R.N., Yaşar, D., 1999. Oscillating Quaternary water levels of the Marmara Sea and vigorous outflow into the Aegean Sea from the Marmara Sea-Black Sea drainage corridor. Marine Geology, 153, 275-302.

Aksu, A.E., Hiscott, R.N., Kaminski, M.A., Mudie, P.J., Gillespie, H., Abrajano, T., Yaşar, D., 2002a. Late-Glacial-Holocene paleoceanography of the Black Sea and Marmara Sea: stable isotopic, foraminiferal and coccolith evidence. Marine Geology, 190, 119-149.

Aksu, A.E., Hiscott, R.N., Yaşar, D., Işler, F.I., Marsh, S., 2002b. Seismic stratigraphy of Late Quaternary deposits from the southwestern Black Sea shelf: evidence for noncatastrophic variations in sea-level during the last $\sim 10000$ yr. Marine Geology, 190, 6194.

Aksu, A.E., Hiscott, R.N., Yaltırak, C., 2016. Early Holocene age and provenance of a midshelf delta lobe south of the Strait of Bosphorus, Turkey, and its links to vigorous Black Sea outflow. Marine Geology, 380, 113-137.

Aladin, N.V., 1993. Salinity tolerance, morphology and physiology of the osmoregulatory organ in Ostracoda with special reference to Ostracoda from the Aral Sea. In: P. Jones, K. McKenzie (Eds.), Ostracoda in the Earth and Life Sciences, A.A. Balkema, Rotterdam, pp. $387-403$.

Athersuch, J., Horne, D.J., Whittaker, J.E., 1989. Marine and brackish water ostracods. Synopses of the British Fauna (New Series) no. 43. The Bath Press, E.J. Brill, Avon. $343 \mathrm{pp}$.

Baird, W., 1850. The Natural History of the British Entomostraca, Ray Society, London, 364 pp, pls. 1-36. 
Bonaduce, G., Ciampo, G., Masoli, M., 1975. Distribution of Ostracoda in the Adriatic Sea. Naples: Stazione Zoologica di Napoli, 40, 1-304.

Boomer, I., Whatley, R.C., Aladin, N., 1996. Aral Sea Ostracoda as environmental indicators. Lethaia, 29, 77-85.

Boomer, I., Horne, D.J., Slipper, I.J., 2003. The use of ostracods in palaeoenvironmental studies, or what can you do with an ostracod shell? Paleontological Society Papers, 9,153-179.

Boomer, I., von Grafenstein, U., Guichard, F., Bieda, S., 2005. Modern and Holocene sublittoral ostracod assemblages (Crustacea) from the Caspian Sea: a unique brackish, deep-water environment. Palaeogeography, Palaeoclimatology, Palaeoecology, 225, 173-186.

Boomer, I., Guichard, F., Lericolais, G., 2010. Late Pleistocene to Recent ostracod assemblages from the western Black Sea. Journal of Micropalaeontology, 29, 119-133.

Bradley, L.R., Marret, F., Mudie, P.J., Aksu, A.E., Hiscott, R.N., 2012. Constraining Holocene sea-surface conditions in the south-western Black Sea using dinoflagellate cysts. Journal of Quaternary Science, 27, 835-843.

Caraion, F.E., 1963. Observatii asupra ostracodelor din basinele salmaste si sup rahaline ale litoralului romanesc al Marii Negre. Studii şi cercetari de Biologie, Seria Zoologie, 14, $111-121$.

Chepalyga, A.L., 2002. The Black Sea. In: A.A. Velichko (Ed.), Development of the northern landscapes and climate: Last Pleistocene-Holocene - perspectives of the future (pp. 205285). Moscow: GEOS. [in Russian]

De Deckker, P., 2002. Ostracod palaeoecology. In: J.A. Holmes, A.R. Chivas (Eds.), The Ostracoda: Applications in Quaternary Research (pp. 121-134). Washington: American Geophysical Union, doi: 10.1029/131GM06 
Dubowsky, N.W., 1939. On the ostracod fauna of the Black Sea. Trudy Karadah. Nauch. Sta. T.I. Vyazemskoho, 5, 1-68. [in Russian]

Eckert, S., H-J., Brumsack, Severmann, S., Schnetger, B., März, C., Fröllje, H., 2013. Establishment of euxinic conditions in the Holocene Black Sea. Geology, 41, 431-434.

Evans, J.M., 2004. Noah's flood: Fact or fiction? A paleoenvironmental study of Holocene Black Sea Ostracoda. Unpublished Masters report, University College London, London, 79 pp. Filipova-Marinova, M., 2007. Archaeological and paleontological evidence of climate dynamics, sea-level change, and coastline migration in the Bulgarian sector of the Circum-Pontic region. In V. Yanko-Hombach, A.S. Gilbert, N. Panin, P.M. Dolukhanov (Eds.), The Black Sea flood question: Changes in coastline, climate and human settlement (pp. 453482). Heidelberg, Springer.

Flood, R.D., Hiscott, R.N., Aksu, A.E., 2009. Morphology and evolution of an anastomosed channel network where saline underflow enters the Black Sea. Sedimentology, 56, 807839.

Giunta, S., Morigi, C., Negri, A., Guichard, F., Lericolais, G., 2007. Holocene biostratigraphy and paleoenvironmental changes in the Black Sea based on calcareous nannoplankton. Marine Micropaleontology, 63, 91-110.

Grimm, E.C., 1987. CONISS: A Fortran 77 program for stratigraphically constrained cluster analysis by the method of incremental sum of squares. Computers and Geosciences, 13, $13-35$.

Grimm E.C., 2011. TILIA software version 1.7.16. Illinois State Museum, Research and Collection Center, Springfield USA - http://intra.museum.state.il.us/pub/grim?m/tilia/. 
Hiscott, R.N., Aksu, A.E., Yaşar, D., Kaminski, M.A., Mudie, P.J., Kostylev, V.E., MacDonald, J.C., Işler, F.I., Lord, A.R., 2002. Deltas south of the Bosphorus strait record persistent Black Sea outflow to the Marmara Sea since 10 ka. Marine Geology, 190, 95-118.

Hiscott, R.N., Aksu, A.E., Mudie, P.J., Kaminski, M., Abrajano, T., Yaşar, D., Rochon, A., 2007a. The Marmara Sea Gateway since $\sim 16$ ka: non-catastrophic causes of paleoceanographic events in the Black Sea at 8.4 ka and 7.15 ka. In: Yanko- Hombach, V., Gilbert, A.S., Panin, N., Dolukhanov, P.M. (Eds.), The Black Sea Flood Question: Changes in Coastline, Climate and Human Settlement. Springer, Dordrecht, pp. 89-117.

Hiscott, R.N., Aksu, A.E., Mudie, P.J., Marret, F., Abrajano, T., Kaminski, M.A., Evans, J., Çakıroğlu, A., Yaşar, D., 2007b. A gradual drowning of the southwestern Black Sea shelf: evidence for a progressive rather than abrupt Holocene reconnection with the eastern Mediterranean Sea through the Marmara Sea Gateway. Quaternary International, 167-168, 19-34.

Hiscott, R.N., Aksu, A.E., Mudie, P.J., Marret, F., Abrajano, T., Kaminski, M.A., Evans, J., Çakıroğlu, A., Yaşar, D., 2010. Corrigendum to "A gradual drowning of the southwestern Black Sea shelf: Evidence for a progressive rather than abrupt Holocene reconnection with the eastern Mediterranean Sea through the Marmara Sea Gateway" [Quaternary International, 167-168 (2007), 19-34]. Quaternary International, 226, 160.

Hiscott, R.N., Aksu, A.E., Flood, R.D., Kostylev, V., Yaşar, D., 2013. Widespread overspill from a saline density-current channel and its interaction with topography on the southwest Black Sea shelf. Sedimentology, 60, 1639-1667. 
Hiscott, R.N., Aksu, A.E., Yaltırak, C., 2017. Modelling the provenance of detritus flushed through the Strait of Bosphorus, Turkey, during early Holocene outflow from the Black Sea to the world ocean. Marine Geology, 390, 147-169.

Intergovernmental Oceanographic Commission (IOC), 1981. International Bathymetric Chart of the Mediterranean (Published by the Head Department of Navigation and Oceanography, Russia under the authority of IOC, 10 sheets).

Ivanova, E.V., Murdmaa, I.O., Chepalyga, A.L., Cronin, T.M., Pasechnik, I.V., Levchenko, O.V., Howe, S.S., Manushkina, A.V., Platonova, E.A., 2007. Holocene sea-level oscillations and environmental changes on the Eastern Black Sea shelf. Palaeogeography, Palaeoclimatology, Palaeoecology, 246, 228-259.

Kaminski, M.A., Aksu, A.E., R.N. Hiscott, Box, M., Al-Salameen, M. and Filipescu, S., 2002. Late glacial to Holocene benthic foraminifera in the Marmara Sea. Marine Geology, 190: $165-202$.

Keen, M.C., 1982. Intraspecific variation in Tertiary ostracods. In: R.H. Bates, E. Robinson, L.M. Sheppard (Eds.), Fossil and Recent Ostracods, pp. 381-405, Chichester: Ellis Horwood Ltd.

Kerey, I.E., Meriç, E., Tunoğlu, C., Kelling, G., Brenner, R.L., Doğan, A.U., 2004. Black SeaMarmara Sea Quaternary connections: new data from the Bosphorus, İstanbul, Turkey. Palaeogeography, Palaeoclimatology, Palaeoecology, 204, 277-295.

Lambeck, K., Sivan, D., Purcell, A., 2007. Timing of the last Mediterranean Sea - Black Sea connection from isostatic models and regional sea-level data. In: Yanko- Hombach, V., Gilbert, A.S., Panin, N., Dolukhanov, P.M. (Eds.), The Black Sea Flood Question: Changes in Coastline, Climate and Human Settlement. Springer, Dordrecht, pp. 797-808. 
Lane-Serff, G.F., Rohling, E.J., 1997. Postglacial connection of the Black Sea to the Mediterranean and its relation to the timing of sapropel formation. Paleoceanography, $12,169-174$.

Latif, M.L., Özsoy, E., Salihoğlu, I., Gaines, A.F., Başturk, Ö., Yılmaz, A., Tuğrul, S., 1992. Monitoring via direct measurements of the modes of mixing and transport of waste-water discharges into the Bosphorus underflow. Middle East Technical University, Institute of Marine Sciences, Technical Report, 92-2, 98 pp.

Livental, V.E., 1929. Ostracoda of Akchagilian and Apsheronian beds of the Babazan Section. Izvestiya Azerbajdzahnskogo Politekhnischeskogo Instituta, 1, 1-58. [In Russian]

Livental, V.E., 1938. Deposits and microfaunaof the Baku area. Azerbaijan Scientific Research Institute for Petroleum Transactions, 1, 46-67. [in Russian]

Major, C., Ryan, W., Lericolais, G., Hajdas, I., 2002. Constraints on Black Sea outflow to the Sea of Marmara during the last glacial-interglacial transition. Marine Geology, 190, 1934.

Major, C.O., Goldstein, S.L., Ryan, W.B.F., Lericolais, G., Piotrowski, A.M., Hajdas, I., 2006. The co-evolution of Black Sea level and composition through the last deglaciation and its paleoclimate significance. Quaternary Science Reviews, 25, 2031-2047.

Marret, F., Mudie, P.J., Aksu, A.E., Hiscott, R.N., 2009. A Holocene dinocyst record of a two-step transformation of the Neoeuxinian brackish water lake into the Black Sea. Quaternary International, 197, 72-86.

Martin, R.E., Leorri, E., McLaughlin, P.P., 2007. Holocene sea level and climate change in the Black Sea: Multiple marine incursions related to freshwater discharge events. Quaternary International, 167-168, 61-72. 
Mertens, K.N., Bradley, L.R., Takano, Y., Mudie, P.J., Marret, F., Aksu, A.E., Hiscott, R.N., Verleye, T.J., Mousing, E.A., Smyrnova, L.L., Bagheri, S., Mansor, M., Pospelova, V., Matsuoka, K., 2012. Quantitative estimation of Holocene surface salinity variation in the Black Sea using dinoflagellate cyst process length. Quaternary Science Reviews, 39, 4559.

Mudie, P.J., Rochon, A., Aksu, A.E., Gillespie, H., 2002. Dinoflagellate cysts and freshwater algae and fungal spores as salinity indicators in Late Quaternary cores from Marmara and Black Seas. Marine Geology, 190: 203-231.

Mudie, P.J., Marret, F., Aksu, A.E., Hiscott, R.N., Gillespie, H., 2007. Palynological evidence for climate change, anthropogenic activity and outflow of Black Sea water during the late Pleistocene and Holocene: Centennial- to decadal- scale records from the Black and Marmara Seas. Quaternary International, 167-168, 73-90.

Mudie, P.J., Yanko-Hombach, V., Kadurin, S., 2014. The Black Sea dating game and Holocene marine transgression. Open Journal of Marine Science, 4, 1-7.

Müller, G.W., 1894. Die Ostracoden des Golfes von Neapel und der angrenzenden Meeresabschnitte. In: Fauna und Flora des Golfes von Neapel 21. VIII, 404 pp., 40 pls., R. Friedlander, Berlin.

Murray, J.W., İzdar, E., 1989. The 1988 Black Sea Oceanographic Expedition: overview and new discoveries. Oceanography, 2, 15-16.

Neale, J.W., 1988. Ostracods and palaeosalinity reconstruction. In P. De Deckker, J.P. Colin, J.P. Peypouquet (Eds.), Ostracoda in the Earth Sciences, Elsevier, The Netherlands, pp. 125-155. 
Opreanu, P.A., 2008. Ostracode relicte Ponto-Caspice in sectorul Romanecs Aal Marii Negre. Geo Eco Marina, 14, 57-62.

Özsoy, E., Latif, M.A., Tuğrul, S, Ünlülata, Ü., 1995. Exchanges with the Mediterranean, fluxes and boundary mixing processes in the Black Sea. In: F. Briand (Ed.), Mediterranean Tributary Seas. Spec. Publ. 15, CIESME Science Series, Vol. 1 (pp. 1-25). Monaco: Bulletin de l'Institut Océanographique.

Özsoy, E., Di Iorio, D., Gregg, M., Backhaus, J.O., 2001. Mixing in the Bosphorus Strait and the Black Sea continental shelf: observations and a model of the dense water outflow. Journal of Marine Systems, 31, 99-135.

Penny, D.N., 1993. Northern North Sea benthic Ostracoda: modern distribution and paleoenvironmental significance. The Holocene, 3, 241-254.

Panin, N., Strechie, C., 2006. Late Quaternary sea-level and environmental changes in the Black Sea: A brief review of published data. The Journal of Archaeomythology, 2, 3-16.

Poag, C.W., Valentine, P.C., 1976. Biostratigraphy and ecostratigraphy of the Pleistocene basin, Texas-Louisiana continental shelf. Gulf Coast Association of Geological Societies 26th Annual Convention, 185-256.

Puri, H., Bonaduce, G., Malloy, J., 1964. Ecology of the Gulf of Naples. Pubblicazioni della Stazione Zoological di Napoli, 33, 87-199.

Reimer, P. J., Bard, E., Bayliss, A., Beck, J. W., Blackwell, P. G., Bronk Ramsey, C., Grootes, P. M., Guilderson, T. P., Haflidason, H., Hajdas, I., HattŽ, C., Heaton, T. J., Hoffmann, D. L., Hogg, A. G., Hughen, K. A., Kaiser, K. F., Kromer, B., Manning, S. W., Niu, M., Reimer, R. W., Richards, D. A., Scott, E. M., Southon, J. R., Staff, R. A., Turney, C. S. 
M., van der Plicht, J., 2013. IntCal13 and Marine13 Radiocarbon Age Calibration Curves 0-50,000 Years cal BP. Radiocarbon, 55, 1869-1887.

Reynolds, R., 2012. Carbon and sulphur elemental and isotopic results in a long piston core recovered from the southwestern Black Sea: correlations with core M02-45P. Unpublished BSc thesis, Memorial University of Newfoundland, 101 pp. plus figures.

Roemer, F.A., 1838. Die Cytherinen des Molasse-Gebirges. Neues Jahrbuch fuer Mineralogie, Geognosie, Geologie und Petrefaktenkunde, 5, 514-519.

Ruggieri, G., 1950. Gli Ostracodi delle sabbie grigie quaternarie (Milazziano) di Imola Part 1. Giornale di Geologica, Annali del Museo Geologico di Bologna. Serie 2. 21, 1-57.

Ruggieri, G., 1964. Ecological remarks on the present and past distribution of four species of Loxoconcha in the Mediterranean. Pubblicazioni della Stazione Zoologica di Napoli, 33, $515-528$.

Ruggieri, G., 1967. Due ostracofaune del Miocene allocto dell val Mareccia (Appennino Settentrionale). Rivista Italiana di Paleontologia e Stratigrafia, 73, 351-384.

Ryan, W.B.F., 2007. Status of the Black Sea flood hypothesis. In: Yanko- Hombach, V., Gilbert, A.S., Panin, N., Dolukhanov, P.M. (Eds.), The Black Sea Flood Question: Changes in Coastline, Climate and Human Settlement. Springer, Dordrecht, pp. 63-88.

Ryan, W.B.F., Pitman, W.C., 1998. Noah's flood: The new scientific discoveries about the event that changed history. Touchstone Book, Simon \& Schuster, New York, 319 pp.

Ryan, W.B.F., Pitman, W.C., III, Major, C.O., Shimkus, K., Maskalenko, V., Jones, G.A., Dimitrov, P., Görür, N., Sakınç, M., Yüce, H., 1997. An abrupt drowning of the Black Sea shelf. Marine Geology, 138, 119-126. 
Ryan, W.B.F., Major, C.O., Lericolais, G., Goldstein, S.L., 2003. Catastrophic Flooding of the Black Sea. Annual Review of Earth and Planetary Sciences 31, 525-554.

Sars, G.O., 1866. Oversigt af Norges marine Ostracoder. Forhandlinger i Videnskabs-Selskabet i Christiania. 1865 (1), 1-130.

Schornikov, E.I., 1964. An experiment on the distinction of the Caspian elements of the ostracod fauna in the Azov-Black Sea basin. Zoologicheski Zurnal, 43, 1276-1293. [in Russian]

Schornikov, E.I., 1966. Leptocythere (Crustacea, Ostracoda) of the Azov-Black Sea basin. Zoologicheski Zurnal, 45, 32-49. [in Russian]

Schornikov, E.I., 1967. Identification key to the fauna of the Black Sea and Azov Sea. Free Living Invertebrates, Vol. 2. Crustacean. Kiev. [in Russian]

Schornikov, E. I., 1969. Subclass Ostracoda, shelled Crustacea-Ostracoda. In: Opredelitel' fauny Chernogo i Azovskogo morey, tom 2, Rakoobraznye (Key to the Fauna of the Black and Azov Seas, 2. Free Living Invertebrates-Crustacea, pp. 163-260. Kiev: Naukova dumka. [in Russian]

Schweyer, A.V., 1949. On the Pliocene Ostracoda of the northern Caucasus and lower Volga region. Trudy Vesoyuznogo Neftyanogo Naucho-Isseldovatelskogo GeologoRazvedochnogo Instituta, 30, 9-68. [in Russian]

Seguenza, G., 1884. Gli Ostracodi del porto di Messina (9). Il Naturalista Siciliano, 4, 44-48.

Siani, G., Paterne, M., Arnold, M., Bard, E., Métiver, B., Tisnerat, N., Bassinot, F., 2000. Radiocarbon reservoir ages in the Mediterranean Sea and Black Sea. Radiocarbon, 42, 271-280. 
Soulet, G., Delaygue, G., Vallet-Coulomb, C., Böttcher, M.E., Sonzogni, C., Lericolais, G., Bard, E., 2010. Glacial hydrologic conditions in the Black Sea reconstructed using geochemical pore water profiles. Earth and Planetary Science Letters, 296, 57-66.

Soulet, G., Ménot, G., Garreta, V., Rostek, F., Zaragosi, S., Lericolais, G., Bard, E., 2011. Black Sea 'lake' reservoir age evolution since the Last Glacial - hydrologic and climatic implications. Earth and Planetary Science Letters 308, 245-258.

Stancheva, M., 1989. Taxonomy and biostratigraphy of the Pleistocene ostracods of the western Black Sea shelf. Geologica Balcanica, 19, 3-39.

Stepanaitys, N., 1958. New forms of ostracods from the Bakunian deposits of western Turkmenistan. Izvestiya Akademia Nauk Turkmenistan SSR, 2, 11-20. [in Russian]

Stepanaitys. N.E., 1962. In: Mandelstam, M.I., Markova, L., Rosyeva, T., Stepanaitys, N., Ostracods from Pliocene and post-Pliocene deposits of Turkmenistan. Izvestiya Akademii Nauk Turkmenskoi SSR, 228 pp. [in Russian].

Stuiver, M., Braziunas, T.F., 1993. Modelling atmospheric ${ }^{14} \mathrm{C}$ influences and ${ }^{14} \mathrm{C}$ ages of marine samples to 10,000 BC. Radiocarbon, 35, 137-189.

Williams, L.R., 2012. Holocene ostracod paleoecology of the southwestern Black Sea shelf. Unpublished MSc thesis, Memorial University of Newfoundland, NL, Canada, 201 pp.

Yanchilina, A.G., Ryan, W.B.F., McManus, J.F., Dimitrov, P., Dimitrov, D., Salvova, K., Filipova-Marinova, M., 2017. Compilation of geophysical, geochronological, and geochemical evidence indicates a rapid Mediterranean-derived submergence of the Black Sea's shelf and subsequent substantial salinification in the early Holocene. Marine Geology, 383, 14-34. 
Yanko-Hombach , V., Gilbert, A.S., Dolukhanov, P., 2007. Controversy over the great flood hypotheses in the Black Sea in light of geological, paleontological, and archaeological evidence. Quaternary International, 167-168, 91-113.

Zenina, M.A., Ivanova, E.V., Bradley, L.R., Murdmaa, I.O., Schornikov, E.I., Marret, F., 2017. Origin, migration pathways, and paleoenvironmental significance of Holocene ostracod records from the northeastern Black Sea shelf. Quaternary Research, 87, 49-65. 


\section{Figure captions}

Figure 1. Location map showing the Black Sea and its connection to the Aegean Sea via the Marmara Sea Gateway. M02-45/M05-03 and M05-50/51 locate cores M02-45T/P, M0503P and M05-50P, M05-51G, respectively (described in text). Distances between individual cores and their penetrations are shown in Figs. 3 and 4. The last glacial maximum (LGM) shoreline is drawn at the $\sim 125 \mathrm{~m}$ isobath (IOC, 1981). At that time, the water body labelled as the Black Sea was instead the Neoeuxine Lake. Topography and bathymetry compiled using GeoMapApp (Ryan et al., 2009) in Global Mapper. Coastline and rivers are from NOAA National Geophysical Data Center (http://www.ngdc.noaa.gov/mgg/shorelines/shorelines.html).

Figure 2. Sun-illuminated multibeam bathymetry of the southwestern Black Sea immediately north of the Strait of Bosphorus, showing the prominent saline channel (created using Caris Base Editor 4.1) and the locations of the cores collected during the MAR05 cruise. Cores M05-50P and M05-51G are described in text. The multibeam data were collected during the M05, M08 and M11 cruises of the R/V Koca Piri Reis of the Dokuz Eylül University, and are fully described and interpreted in Flood et al. (2009) and Hiscott et al. (2013). Coastline is digitized in Google Earth. Isobaths are created in Global Mapper. The 50 and $100 \mathrm{~m}$ isobaths outside the detailed multibeam area are from the International Bathymetric Charts of the Mediterranean (IOC, 1981).

Figure 3. Huntec DTS boomer profile collected during the MAR2005 cruise showing the acoustic character of the Holocene sedimentary successions across the southwestern Black Sea and the along-strike projections of core sites M02-45P/T and M05-03P to this line. Vertical resolution is $\sim 25 \mathrm{~cm}$. Reflectors $\alpha$ and $\alpha 2$ are unconformities described 
and interpreted in Aksu et al. (2002) and onlapped by younger strata. Reflector $\alpha 1$ appears to show mild local truncation of underlying reflectors so might be a disconformity around the core sites, although no evidence for this is present in the age model or visual descriptions. Elsewhere across the southwestern Black Sea shelf, $\alpha 1$ is interpreted by Hiscott et al. (2007b) and Flood et al. (2009) as a subaqueous erosion surface. Considering projection distances, the extent of basal onlap between the M0245P/T and M05-03P sites cannot be estimated from this graphic. Water depth and sediment thicknesses are calculated using an acoustic velocity of $1500 \mathrm{~m} \mathrm{~s}^{-1}$. Vertical exaggeration $\mathrm{VE}=27 \mathrm{x}$; f 926.5-f 927.5 are fix numbers assigned during the survey. Location is shown in the inset.

Figure 4. Huntec DTS boomer profile collected during the MAR2005 cruise showing the acoustic character of the Holocene sedimentary successions across the southwestern Black Sea and the along-strike projections of core sites MAR05-50P and MAR05-51G to this line. This profile is part of a 200 line-km grid of Huntec data around the core sites. Vertical resolution is $\sim 25 \mathrm{~cm}$. Reflectors $\alpha, \alpha 1$ and $\alpha 2$ are unconformities (the latter only locally in this area described and interpreted in Aksu et al. (2002), Hiscott et al. (2007b) and Flood et al. (2009); all are onlapped by younger strata. Water depth and sediment thicknesses are calculated using an acoustic velocity of $1500 \mathrm{~m} \mathrm{~s}^{-1}$. Vertical exaggeration $\mathrm{VE}=27 \mathrm{x} ; \mathrm{f} 1063-\mathrm{f} 1064$ are fix numbers assigned during the survey. Location is shown in the inset.

Figure 5. Paired downcore plots of total organic carbon (TOC), total sulphur (TS) and $\delta^{34} \mathrm{~S}$ for (a) gravity and piston cores M02-45T and M02-45P (correlated as justified by Hiscott et al., 2007b, with $110 \mathrm{~cm}$ core-top loss in M02-45P) and (b) piston core M05-03P. M05- 
03P apparently had its trip wire set incorrectly during coring so that core-top loss is 302 cm. For analytical methods, see Hiscott et al. (2007b). Several key peaks, troughs, and abrupt steps in the plots lead to an unambiguous correlation, and to the conclusion that M05-03P extends into older sediment than M02-45P. Its lowermost facies also are consistent with intersection of gravelly lag deposits along the $\alpha$ unconformity. This facies is absent in M02-45P.

Figure 6. Simplified lithostratigraphy of the composite cores M02-45 (left) and M05-50 (right) showing the positions of the lithological units (discussed in text) and the radiocarbon dates (shown as calendar years before present, cal yr BP; see Table 1 for raw ${ }^{14} \mathrm{C}$ ages). In the case of M02-45, the splice with core M05-03P (adding $78 \mathrm{~cm}$ to the base of the composite) used three geochemical markers found in both piston cores at that site, and marked in Fig. 5. The age versus depth plots show the 2305 years hiatus at the $\alpha 1$ unconformity in core M05-50 and the 3025 years hiatus at the $\alpha 2$ unconformity in core M02-45. Note that the $\alpha 2$ reflector which is a local unconformity at core site M02-45 is apparently a conformable surface at core site M05-50. Conversely, the $\alpha 1$ reflector which is a local unconformity at core site M05-50 is apparently a conformable surface at core site M02-45. Location is shown in Figure 1.

Figure 7. Summary of interpreted reservoir ages for shallow waters of the latest Quaternary Black Sea. Yanchilina et al. (2017) proposed but did not explain the reason for an abrupt rise in $R$ several centuries before reconnection to the world ocean. Dashed lines and question marks denote uncertainty noted in the original articles. The default Marine13 modelled reservoir age from $\sim 450-7100{ }^{14} \mathrm{C}$ yr BP was calculated by determining the difference between the Marine13 and IntCal13 defining curves (Reimer et al., 2013), the 
latter smoothed with a 9-point moving average to mimic the natural smoothing of the marine record (Stuiver and Braziunas, 1993). In this paper, calibrations of mollusc ages at the M02-45 core site use $R$ values picked from the blue trend.

Figure 8. $\delta^{13} \mathrm{C}$ and $\delta^{18} \mathrm{O}$ trends for stalagmites from the Sofular Cave, Turkey, presented as raw data (thin blue trends) and 5-point moving averages (bold gray trends) plotted against atmospheric ${ }^{14} \mathrm{C}$ ages converted from original $\mathrm{U} / \mathrm{Th}$ dates on stalagmite samples using the IntCal13 data set. Superimposed are scatterplots of $\delta^{13} \mathrm{C}$ and $\delta^{18} \mathrm{O}$ data from Black Sea molluscs (Yanchilina et al., 2017, their supplementary file mmc6.xlsx). Red scales relate to red data points for molluscs, and black scales relate to Sofular Cave trendlines. Parts a and $\mathrm{b}$ plot the mollusc results using uncorrected ${ }^{14} \mathrm{C}$ dates; parts $\mathrm{c}$ and $\mathrm{d}$ incorporate reservoir corrections proposed by Yanchilina et al. (2017; consistent with their curve in Fig. 7); parts e and f use reservoir ages preferred by the authors (labelled as "this paper $\mathrm{R}$ " in Fig. 7). Reservoir age is an intrinsic property of the dissolved inorganic carbon (DIC) in the seawater of the day, so must be applied identically to each pair of isotopic plots. $\quad \mathrm{BA}=\mathrm{B} \varnothing$ lling/Allerød 'trough' in $\delta^{13} \mathrm{C}$ that effectively dictates the choice of appropriate reservoir ages before $\sim 11000{ }^{14} \mathrm{C}$ yr BP. Circled $1=$ cluster of $\delta^{13} \mathrm{C}$ data points $(2-3 \%)$ which cannot be adjusted to fit the slightly older peak in the Sofular Cave trend because reservoir offsets can only shift marine radiocarbon ages downward. Circled 2 = swath of time $\left(\sim 8200-10000{ }^{14} \mathrm{C}\right.$ yr BP $)$ devoid of mollusc results when ages are corrected using Yanchilina et al. (2017) parameters, because high $R$ values squeeze raw ${ }^{14} \mathrm{C}$ dates in this interval to younger ages (compare parts a and c). Circled $3=$ cluster of $\delta^{18} \mathrm{O}$ data points conspicuously shifted away from the Sofular Cave trend by Yanchilina et al. (2017) procedures, but not by author calibrations (compare parts d and 
f). Circled $4=$ cluster of $\delta^{18} \mathrm{O}$ data points which poorly fit the Sofular Cave trend, but which cannot be moved by increasing the reservoir age because this would destroy the fine match between $\delta^{13} \mathrm{C}$ mollusc data and the Bølling/Allerød "trough", which cannot be abandoned because it is the most compelling match in the $\delta^{13} \mathrm{C}$ plots.

Figure 9. Plot of uncalibrated radiocarbon age versus the depositional elevation (relative to modern sea level $=$ rmsl) of 123 dated shells extracted from Memorial University of Newfoundland cores raised from the modern southwestern Black Sea shelf. The authors agree with Yanchilina et al. (2017) that the shelf was fully flooded to an elevation of -40 $\mathrm{m}$ rmsl (or above) since $\sim 8750{ }^{14} \mathrm{C}$ yr BP; the senior authors have proposed (Aksu et al., 2016) that this elevation was reached and maintained earlier, by $\sim 11.1 \mathrm{cal} \mathrm{ka}\left(\sim 10.1{ }^{14} \mathrm{C}\right.$ ka). Even the younger estimate of Yanchilina et al. (2017) requires that both the $\alpha 1$ and $\alpha 2$ levels at site M02-45 developed under tens of meters of water as submarine conformities/unconformities because sediments beneath these horizons are younger than $\sim 7.0{ }^{14} \mathrm{C}$ ka and $\sim 5.1{ }^{14} \mathrm{C}$ ka, respectively (annotated arrows to right side). Twenty dated shells (white symbols) come from modern depths which Yanchilina et al. (2017) propose to have been subaerial; instead, these D. polymorpha, D. rostriformis, Theodoxus spp. and Turricaspia spica shells confirm subaqueous conditions on the earliest Holocene southwestern shelf. The lack of data from water depths less than about $-60 \mathrm{~m}$ attests to the steep inclination of the coastal profile in this area so that most of the shelf is deeper than $\sim-50 \mathrm{~m}$ (Aksu et al., 2002, their figure 2).

Figure 10. Number of ostracod valves counted in composite cores M02-45 and M05-50. All valves were picked in each sample, so for samples of approximately equal volume, number of counts provides an indication of the richness of the samples. Notice that in 
M02-45, off-scale peaks are located very close to unconformities $(\alpha, \alpha 2)$ or intervals of slow accumulation ( $\alpha 1$, Fig. 5).

Figure 11. Scanning electron microscope images of key Ponto-Caspian ostracod species. (1) Amnicythere cymbula (left valve, LV), M05-50 $690 \mathrm{~cm}$ (2) Amnicythere olivia (LV) M05-50 $580 \mathrm{~cm}$ (3) Amnicythere quinquetuberculata (LV), M05-50 $770 \mathrm{~cm}$ (4) Amnicythere sp. aff. subcaspia (LV), M05-50 $740 \mathrm{~cm}$ (5) Graviacypris elongate (right valve, RV), M05-50 640 cm (6) Euxinocythere bacuana (LV), M05-50 $680 \mathrm{~cm}$ (7) Tyrrhenocythere amnicola donetziensis (RV), M05-50 $780 \mathrm{~cm}$ (8) Loxoconchissa (Loxocaspia) immodulata (LV), M05-50 $660 \mathrm{~cm}$ (9) Loxoconcha lepida (female, LV), M05-50 720 cm (10) Loxoconcha lepida (male, RV), M05-50 720 cm (11) Loxoconcha sublepida (LV), M05-50 720 cm (12) Euxinocythere sp. aff. relicta (RV), M05-50 760 cm. Scale bars $=100 \mu \mathrm{m}$.

Figure 12. Scanning electron microscope images of key Mediterranean ostracod species. (1) Amnicythere propinqua (LV), M05-50 $120 \mathrm{~cm}$ (2) Callistocythere diffusa (LV), M05-50 $120 \mathrm{~cm}$ (3) Carinocythereis carinata (female, LV), M05-50 $350 \mathrm{~cm}$ (4) Carinocythereis carinata (male, LV), M05-50 $350 \mathrm{~cm}$ (5) Costa edwardsi (LV), M05-50 $50 \mathrm{~cm}$ (6) Cytheroma variabilis (LV), M05-50 $120 \mathrm{~cm}$ (7) Hiltermannicythere rubra (LV), M05-50 $330 \mathrm{~cm}$ (8) Leptocythere multipunctata (LV), M05-50 $350 \mathrm{~cm}$ (9) Sagmatocythere littoralis (LV), M05-50 $580 \mathrm{~cm}$ (10) Pterygocytheris jonesii (LV) M05-50 $370 \mathrm{~cm}$ (11) Palmoconcha agilis (female, LV), M05-50 $430 \mathrm{~cm}$ (12) Palmoconcha agilis (male, LV), M05-50 430 cm (13) Xestoleberis sp. aff. cornelii (RV), M05-50 390 cm, (14), Paracypris polita (RV), M05-50 $20 \mathrm{~cm}$. Scale bars $=100 \mu \mathrm{m}$. 
Figure 13. Population age diagrams for key species from irregularly spaced depths throughout composite core MAR05-50. The presence of adults (A) and various juveniles (A-1 through A-6) confirms an autochthonous assemblage on which an environmental interpretation can be based. Gray and green bars indicate brackish and marine species, respectively.

Figure 14. Downcore variations of key Mediterranean (blue line-green fill) and Ponto-Caspian (red line-gray fill) ostracod species in composite core MAR05-50, shown in percent abundances of total fauna in depth domain. Lithostratigraphic Units 1-3 and $\alpha 1$ surface are explained in text. Core location is shown in Figures 1 and 2.

Figure 15. Downcore variations of key Mediterranean (blue line-green fill) and Ponto-Caspian (red line-gray fill) ostracod species in composite MAR02-45, shown in percent abundances of total fauna in depth domain (partial data from Evans, 2004). Lithostratigraphic Units A-D, $\alpha$ and $\alpha 2$ unconformities, and the $\alpha 1$ surface are explained in text. Core location is shown in Figures 1 and 3.

Figure 16. CONISS cluster analysis results show that core MAR05-50 can be divided into six bioecozones (1-6) based on distinct assemblages of key ostracod species, reflecting stepby-step ecological changes that took place in the Black Sea driven by gradual salination following the post-glacial reconnection to the Mediterranean Sea. Hiatus at $\alpha 1$ is described in text.

Figure 17. CONISS cluster analysis results show that core MAR02-45 can be divided into six bioecozones (1-6) based on distinct assemblages of key ostracod species, reflecting stepby-step ecological changes that took place in the Black Sea driven by gradual salination 
following the post-glacial reconnection to the Mediterranean Sea. Hiatus at $\alpha 2$ is described in text.

Figure 18. Synthesis of CONISS results and the associated Bioecozones across the southwestern Black Sea shelf. Purple lines with italicized purple numbers are bioecozone boundaries and their ages in cal yr BP. Pink highlight depicts the estimated lateral extents of the hiatuses at $\alpha 1$ and $\alpha 2$ (described in text). Salinity estimates in brackets for each bioecozone are explained in text. Downcore plots of the total Mediterranean versus total Ponto-Caspian assemblages (at far right and far left) show the co-occurrence of Mediterranean and Ponto-Caspian species associated with the dramatic faunal turnover during Bioecozone 3. 
Table 1. Radiocarbon ages for cores M02-45T, M02-45P, M05-03P, M05-50P and M05-51G reported as conventional ${ }^{14} \mathrm{C}$ dates (half-life of 5568 years; errors represent $68.3 \%$ confidence limits), calibrated to calendar years using the Marine13 data set and reservoir ages from Fig. 7. Bold dates are not used in the age models for this paper. Calibrations of raw dates younger than $7.0{ }^{14} \mathrm{C}$ ka are effectively identical to those of Mertens et al. (2012). TO = IsoTrace Radiocarbon Laboratory, Accelerator Mass Spectrometry Facility, University of Toronto. UC $=$ UCIAMS $=$ Radiocarbon Dating Laboratory, Université Laval, in collaboration with KECK Carbon Cycle AMS Facility, University of California, Irvine. BETA = BETA Analytic, Miami. $\mathrm{T}=$ trigger-weight core; $\mathrm{P}=$ piston core.

\begin{tabular}{|c|c|c|c|c|c|c|c|}
\hline Core & $\begin{array}{l}\text { Dept } \\
\mathrm{h}\end{array}$ & $\begin{array}{l}\text { Composit } \\
\mathrm{e}\end{array}$ & Material dated & Raw date & $\Delta \mathrm{R}$ & $\begin{array}{l}\text { Calendar } \\
\text { Age }\end{array}$ & Lab number \\
\hline & $(\mathrm{cm})$ & $\begin{array}{l}\text { depth } \\
(\mathrm{cm})\end{array}$ & & $\begin{array}{l}\left({ }^{14} \mathrm{C} \quad \mathrm{yr}\right. \\
\mathrm{BP})\end{array}$ & $\begin{array}{l}\left({ }^{14}\right. \\
C \\
y r)\end{array}$ & (cal yr BP) & \\
\hline $\begin{array}{l}\mathrm{M} 02 \\
-45 \mathrm{~T}\end{array}$ & 92 & 92 & Spisula subtruncata & $730 \pm 50$ & +10 & $365 \pm 50$ & TO-11433 \\
\hline $\begin{array}{l}\mathrm{M} 02 \\
-45 \mathrm{P}\end{array}$ & 33 & 143 & Spisula subtruncata & $730 \pm 40$ & +10 & $365 \pm 45$ & TO-11435 \\
\hline $\begin{array}{l}\mathrm{M} 02 \\
-45 \mathrm{~T}\end{array}$ & 145 & 145 & Spisula subtruncata & $770 \pm 50$ & +10 & $395 \pm 55$ & TO-11434 \\
\hline $\begin{array}{l}\mathrm{M} 02 \\
-45 \mathrm{P}\end{array}$ & 158 & 268 & $\begin{array}{l}\text { Mytilus } \\
\text { galloprovincialis }\end{array}$ & $2400 \pm 60$ & +10 & $2025 \pm 80$ & TO-11006 \\
\hline $\begin{array}{l}\mathrm{M} 02 \\
-45 \mathrm{P}\end{array}$ & 160 & 270 & $\begin{array}{l}\text { downward } \\
\text { extrapolation }\end{array}$ & & & $2055 \pm \sim 85$ & $\alpha 2$ level \\
\hline $\begin{array}{l}\mathrm{M} 02 \\
-45 \mathrm{P}\end{array}$ & 161 & 271 & $\begin{array}{l}\text { upward } \\
\text { extrapolation }\end{array}$ & & & $5445 \pm \sim 55$ & $\alpha 2$ level \\
\hline $\begin{array}{l}\mathrm{M} 02 \\
-45 \mathrm{P}\end{array}$ & 174 & 284 & $\begin{array}{l}\text { Mytilus } \\
\text { galloprovincialis }\end{array}$ & $5115 \pm 20$ & +10 & $5480 \pm 40$ & UC-85907 \\
\hline $\begin{array}{l}\mathrm{M} 02 \\
-45 \mathrm{P}\end{array}$ & 220 & 330 & $\begin{array}{l}\text { Mytilus } \\
\text { galloprovincialis }\end{array}$ & $5190 \pm 50$ & +10 & $5535 \pm 55$ & TO-11436 \\
\hline M02 & 302 & 412 & Mytilus & $5900 \pm 60$ & +10 & $6310 \pm 65$ & TO-11437 \\
\hline
\end{tabular}




\begin{tabular}{|c|c|c|c|c|c|c|c|}
\hline$-45 \mathrm{P}$ & & & galloprovincialis & & & & \\
\hline $\begin{array}{l}\text { M05 } \\
-03 \mathrm{P}\end{array}$ & 183 & 485 & Cardium edule & $6810 \pm 25$ & +10 & $7330 \pm 35$ & UC-85908 \\
\hline $\begin{array}{l}\mathrm{M} 02 \\
-45 \mathrm{P}\end{array}$ & 406 & 516 & Monodacna pontica & $7560 \pm 60$ & -12 & $8030 \pm 70$ & TO-11438 \\
\hline $\begin{array}{l}\text { M05 } \\
-03 \mathrm{P}\end{array}$ & 226 & 528 & $\begin{array}{l}\text { Adacna } \\
\text { ?laeviuscula }\end{array}$ & $7785 \pm 25$ & -42 & $8305 \pm 45$ & UC-85911 \\
\hline $\begin{array}{l}\mathrm{M} 02 \\
-45 \mathrm{P}\end{array}$ & 495 & 605 & $\begin{array}{l}\text { Truncatella } \\
\text { subcylindrica }\end{array}$ & $8380 \pm 70$ & $\begin{array}{l}- \\
145\end{array}$ & $9150 \pm 100$ & TO-11142 \\
\hline $\begin{array}{l}\text { M05 } \\
-03 \mathrm{P}\end{array}$ & 342 & 644 & Monodacna caspia & $8340 \pm 25$ & $\begin{array}{l}- \\
135\end{array}$ & $9070 \pm 55$ & UC-85910 \\
\hline $\begin{array}{l}\mathrm{M} 02 \\
-45 \mathrm{P}\end{array}$ & 569 & 679 & $\begin{array}{l}\text { Didacna } \\
\text { ?praetrigonides }\end{array}$ & $8570 \pm 70$ & $\begin{array}{l}- \\
141\end{array}$ & $9380 \pm 80$ & TO-11439 \\
\hline $\begin{array}{l}\mathrm{M} 02 \\
-45 \mathrm{P}\end{array}$ & 639 & 749 & Didacna spp. & $8620 \pm 70$ & $\begin{array}{l}- \\
143\end{array}$ & $9440 \pm 70$ & TO-11440 \\
\hline $\begin{array}{l}\mathrm{M} 02 \\
-45 \mathrm{P}\end{array}$ & 754 & 864 & \begin{tabular}{|l|} 
Dreissena \\
rostriformis
\end{tabular} & $8840 \pm 70$ & $\begin{array}{l}- \\
184\end{array}$ & $9700 \pm 120$ & TO-11441 \\
\hline $\begin{array}{l}\mathrm{M} 02 \\
-45 \mathrm{P}\end{array}$ & 810 & 920 & $\begin{array}{l}\text { Dreissena } \\
\text { rostriformis }\end{array}$ & $9370 \pm 70$ & $\begin{array}{l}- \\
234\end{array}$ & $10480 \pm 100$ & TO-11007 \\
\hline $\begin{array}{l}\mathrm{M} 02 \\
-45 \mathrm{P}\end{array}$ & 822 & 932 & $\begin{array}{l}\text { Dreissena } \\
\text { polymorpha }\end{array}$ & $9340 \pm 70$ & $\begin{array}{l}- \\
238\end{array}$ & $10450 \pm 100$ & TO-11442 \\
\hline $\begin{array}{l}\mathrm{M} 02 \\
-45 \mathrm{P}\end{array}$ & 835 & 945 & Theodoxus spp. & $9070 \pm 70$ & $\begin{array}{l}- \\
127\end{array}$ & $10010 \pm 115$ & TO-11443 \\
\hline $\begin{array}{l}\text { M05 } \\
-03 \mathrm{P}\end{array}$ & 678 & 980 & Dreissena spp. & $9510 \pm 25$ & $\begin{array}{l}- \\
191\end{array}$ & $10600 \pm 45$ & UC-85909 \\
\hline $\begin{array}{l}\text { M05 } \\
-03 \mathrm{P}\end{array}$ & 712 & 1014 & Dreissena spp. & $\begin{array}{l}10475 \pm 3 \\
0\end{array}$ & $\begin{array}{l}- \\
306\end{array}$ & $12240 \pm 120$ & UC-85912 \\
\hline $\begin{array}{l}\text { M05 } \\
-51 \mathrm{G}\end{array}$ & 145 & 145 & $\begin{array}{l}\text { Mytilus } \\
\text { galloprovincialis }\end{array}$ & $3280 \pm 60$ & +10 & $3095 \pm 95$ & TO 13101 \\
\hline M05 & 44 & 94 & Mytilus & $2590 \pm 90$ & +10 & $2255 \pm 120$ & TO 13095 \\
\hline
\end{tabular}




\begin{tabular}{|c|c|c|c|c|c|c|c|}
\hline$-50 \mathrm{P}$ & & & galloprovincialis & & & & \\
\hline $\begin{array}{l}\text { M05 } \\
-50 P\end{array}$ & 180 & 230 & $\begin{array}{l}\text { Mytilus } \\
\text { galloprovincialis }\end{array}$ & $3240 \pm 50$ & +10 & $3045 \pm 75$ & TO 13096 \\
\hline $\begin{array}{l}\text { M05 } \\
-50 P\end{array}$ & 200 & 250 & $\begin{array}{l}\text { Mytilus } \\
\text { galloprovincialis }\end{array}$ & $3590 \pm 15$ & +10 & $3470 \pm 35$ & $\begin{array}{l}\text { UCIAMS- } \\
96128\end{array}$ \\
\hline $\begin{array}{l}\text { M05 } \\
-50 \mathrm{P}\end{array}$ & 279 & 329 & $\begin{array}{l}\text { Mytilus } \\
\text { galloprovincialis }\end{array}$ & $3250 \pm 70$ & +10 & $3055 \pm 105$ & TO 13097 \\
\hline $\begin{array}{l}\text { M05 } \\
-50 P\end{array}$ & 310 & 360 & $\begin{array}{l}\text { Mytilus } \\
\text { galloprovincialis }\end{array}$ & $4130 \pm 20$ & +10 & $4175 \pm 45$ & $\begin{array}{l}\text { UCIAMS- } \\
96127\end{array}$ \\
\hline $\begin{array}{l}\text { M05 } \\
-50 P\end{array}$ & 340 & 390 & $\begin{array}{l}\text { Mytilus } \\
\text { galloprovincialis }\end{array}$ & $4320 \pm 60$ & +10 & $4435 \pm 90$ & TO 13098 \\
\hline $\begin{array}{l}\text { M05 } \\
-50 \mathrm{P}\end{array}$ & 435 & 485 & $\begin{array}{l}\text { Mytilus } \\
\text { galloprovincialis }\end{array}$ & $5330 \pm 70$ & +10 & $5695 \pm 80$ & TO 13099 \\
\hline $\begin{array}{l}\text { M05 } \\
-50 P\end{array}$ & 550 & 600 & $\begin{array}{l}\text { foraminifera/ostraco } \\
\text { d }\end{array}$ & $7710 \pm 40$ & -50 & $8235 \pm 55$ & $\begin{array}{l}\text { BETA30592 } \\
0\end{array}$ \\
\hline $\begin{array}{l}\text { M05 } \\
-50 P\end{array}$ & 620 & 670 & $\begin{array}{l}\text { foraminifera/ostraco } \\
\text { d }\end{array}$ & $8540 \pm 50$ & $\begin{array}{l}- \\
110\end{array}$ & $9320 \pm 70$ & $\begin{array}{l}\text { BETA30592 } \\
1\end{array}$ \\
\hline $\begin{array}{l}\text { M05 } \\
-50 P\end{array}$ & 625 & 675 & $\begin{array}{l}\text { foraminifera/ostraco } \\
\text { d }\end{array}$ & $7570 \pm 40$ & -12 & $8040 \pm 60$ & $\begin{array}{l}\text { BETA30798 } \\
1\end{array}$ \\
\hline $\begin{array}{l}\text { M05 } \\
-50 P\end{array}$ & 645 & 695 & $\begin{array}{l}\text { downward } \\
\text { extrapolation }\end{array}$ & & & $8285 \pm \sim 60$ & $\alpha 1$ level \\
\hline $\begin{array}{l}\text { M05 } \\
-50 P\end{array}$ & 646 & 696 & $\begin{array}{l}\text { upward } \\
\text { extrapolation }\end{array}$ & & & $\begin{array}{l}10755 \pm \sim 10 \\
0\end{array}$ & $\alpha 1$ level \\
\hline $\begin{array}{l}\text { M05 } \\
-50 P\end{array}$ & 670 & 720 & $\begin{array}{l}\text { Dreissena } \\
\text { polymorpha }\end{array}$ & $\begin{array}{l}9880 \pm 11 \\
0\end{array}$ & $\begin{array}{l}- \\
231\end{array}$ & $11095 \pm 135$ & TO 13100 \\
\hline $\begin{array}{l}\text { M05 } \\
-50 P\end{array}$ & 737 & 787 & Dreissena spp. & $\begin{array}{l}10270 \pm 9 \\
0\end{array}$ & $\begin{array}{l}- \\
385\end{array}$ & $12010 \pm 205$ & TO 12915 \\
\hline
\end{tabular}


Table 2. List of most common ostracod species found in the SW Black Sea cores.

\begin{tabular}{|c|c|c|}
\hline Genus and species & Original Author & Figure \\
\hline Amnicythere cymbula & (LIVENTAL, 1929) & Fig.11,\#1 \\
\hline Amnicythere olivia & (LIVENTAl, 1938) & Fig.11, \#2 \\
\hline Amnicythere propinqua & (LIVENTAL, 1929) & Fig.12,\#1 \\
\hline $\begin{array}{l}\text { Amnicythere } \\
\text { quinquetuberculata }\end{array}$ & (SCHWEYER, 1949) & Fig.11,\#3 \\
\hline Amnicythere sp. aff. subcaspia & (LIVENTAL, 1929) & Fig.11, \#4 \\
\hline Amnicythere striatocostata & (SCHWEYER, 1949) & Not shown \\
\hline Bythocythere sp. & SARS, 1866 & Not shown \\
\hline Callistocythere diffusa & (MÜLLER, 1894) & Fig.12,\#2 \\
\hline Carinocythereis carinata & (ROEMER, 1838) & Fig.12,\#3, 4 \\
\hline Costa edwardsi & (ROEMER, 1838) & Fig.12, \#5 \\
\hline Cytheroma variabilis & MÜLLER, 1894 & Fig.12, \#6 \\
\hline Euxinocythere bacuana & (LIVENTAL, 1938) & Fig.11, \#6 \\
\hline Euxinocythere sp. aff. relicta & (SCHWEYER, 1949) & Fig.11, \#12 \\
\hline Graviacypris elongata & (SCHORNIKOV, 1964) & Fig.11, \#5 \\
\hline Hiltermannicythere rubra & (MÜLLER, 1894) & Fig.12,\#7 \\
\hline Leptocythere multipunctata & (SEGUENZA, 1884) & Fig.12, \#8 \\
\hline $\begin{array}{l}\text { Loxoconchissa (Loxocaspia) } \\
\text { immodulata }\end{array}$ & STEPANAITYS, 1962 & Fig.11, \#8 \\
\hline Loxoconcha lepida & STEPANAITYS, 1962 & Fig.11, \#9, 10 \\
\hline Loxoconcha sublepida & STANCHEVA, 1989 & Fig.11, \#11 \\
\hline Palmoconcha agilis & (RUGGIERI, 1967) & Fig.12,\#11, 12 \\
\hline Paracypris polita & SARS, 1866 & Fig.12, \#14 \\
\hline Pterygocythereis jonesii & (BAIRD, 1850) & Fig.12, \#10 \\
\hline Sagmatocythere littoralis & (MÜLLER, 1894) & Fig.12,\#9 \\
\hline $\begin{array}{l}\text { Tyrrhenocythere amnicola } \\
\text { donetziensis }\end{array}$ & (DUBOWSKY, 1939) & Fig.11, \#7 \\
\hline Xestoleberis sp. aff. cornelii & CARAION, 1963 & Fig.12, \#13 \\
\hline
\end{tabular}


Table 3. Predominant ostracod species in Bioecozones 1-6 delineated by CONISS in composite cores M02-45 and M05-50, and their ecological significance for the southwestern Black Sea.

Species with greatest abundance are set in bold.

\begin{tabular}{|c|c|c|c|}
\hline Bioecozones & $\begin{array}{c}\text { Core M02-45 } \\
\text { composite }\end{array}$ & $\begin{array}{c}\text { Core M05-50 } \\
\text { composite }\end{array}$ & $\begin{array}{l}\text { Ecological } \\
\text { significance }\end{array}$ \\
\hline Bioecozone 1 & $\begin{array}{c}\text { L. sublepida, L. lepida, } \\
\text { T. amnicola } \\
\text { donetziensis, } A . \\
\text { quinquetuberculata, A. } \\
\text { olivia, G. elongata }\end{array}$ & $\begin{array}{c}\text { L. sublepida, L. lepida, } \\
\text { T. amnicola } \\
\text { donetziensis, A. } \\
\text { quinquetuberculata, A. } \\
\text { olivia, G. elongata }\end{array}$ & $\begin{array}{l}\text { Low salinity, } \\
\text { possibly 5-8 psu but } \\
\text { not fresh water }\end{array}$ \\
\hline Bioecozone 2 & $\begin{array}{l}\text { L. sublepida, L. lepida, } \\
\text { A. quinquetuberculata, } \\
\text { A. olivia, G. elongata, } \\
\text { A. bacuana }\end{array}$ & $\begin{array}{c}\text { L. sublepida, L. lepida, } \\
\text { T. amnicola } \\
\text { donetziensis, A. } \\
\text { quinquetuberculata, A. } \\
\text { olivia, G. elongata }\end{array}$ & $\begin{array}{l}\text { Brackish, possibly } \\
\text { slight salinity } \\
\text { increase, possible } \\
\text { inflow of } \\
\text { Mediterranean water }\end{array}$ \\
\hline Bioecozone 3 & $\begin{array}{c}\text { Cytheroma, } \text { C. } \\
\text { variabilis, L. lepida, } L . \\
\text { sublepida, A. bacuana, } \\
\text { A. olivia, G. elongata }\end{array}$ & $\begin{array}{l}\text { S. littoralis, } L . \\
\text { sublepida, L. lepida, } T \text {. } \\
\text { amnicola donetziensis, } \\
\text { A. quinquetuberculata, } \\
\text { A. olivia, G. elongata }\end{array}$ & $\begin{array}{l}\text { Post-reconnection } \\
\text { transitional phase, } \\
\text { rising salinity } \\
\text { suitable for co- } \\
\text { occurrence of } \\
\text { brackish and marine } \\
\text { ostracods, possibly } \\
\text { up to } 18 \text { psu }\end{array}$ \\
\hline Bioecozone 4 & $\begin{array}{c}\text { P. agilis, } \boldsymbol{H} \text {. rubra, } L . \\
\text { multipunctata, } X . \text { sp. aff. } \\
\text { cornelli }\end{array}$ & $\begin{array}{c}\text { P. agilis, } \text { C. carinata, } \\
\text { H. rubra, } L . \\
\text { multipunctata, } C . \\
\text { variablis }\end{array}$ & $\begin{array}{c}\text { Salinity increased } \\
\text { allowing new } \\
\text { Mediterranean } \\
\text { species to dominate } \\
\text { - salinity } 18-25 \text { psu }\end{array}$ \\
\hline Bioecozone 5 & P. agilis, C. carinata, & P. agilis, C. carinata, & Introduction of new \\
\hline
\end{tabular}




\begin{tabular}{|c|c|c|c|}
\hline & $\begin{array}{c}\text { H. rubra, } \\
\text { L. multipunctata, } C . \\
\text { variablis, Leptocythere, } \\
\text { Cytheroma }\end{array}$ & $\begin{array}{c}\text { H. rubra, } \\
\text { L. multipunctata, } C . \\
\text { variablis, } P \text {. jonesii, } C \text {. } \\
\text { edwardsi }\end{array}$ & $\begin{array}{c}\text { Mediterranean } \\
\text { sublittoral } \\
\text { species, possible } \\
\text { sealevel rise, } \\
\text { salinity perhaps } \geq 25 \\
\text { psu }\end{array}$ \\
\hline Bioecozone 6 & $\begin{array}{c}\text { P. agilis, C. carinata, } H . \\
\text { rubra, } \\
\text { L. multipunctata, } \boldsymbol{C} . \\
\text { variablis, Leptocythere, } \\
\text { Cytheroma }\end{array}$ & $\begin{array}{l}\text { P. agilis, C. carinata, } \\
\text { H. rubra, P.jonesii, C. } \\
\text { edwardsi, P. polita }\end{array}$ & $\begin{array}{l}\text { New Mediterranean } \\
\text { species, salinity } \\
\text { similar to today }\end{array}$ \\
\hline
\end{tabular}




\section{Highlights}

- Ostracods in two cores from SW Black Sea show a slow, time-lagged salination

- Between 12000-7425 cal yr BP ostracods are dominated by Ponto-Caspian species

- From 7425-6315 cal yr BP ostracods consist of Mediterranean and Ponto-Caspian species

- After $\sim 6315$ cal yr BP the assemblage consists exclusively of Mediterranean species 


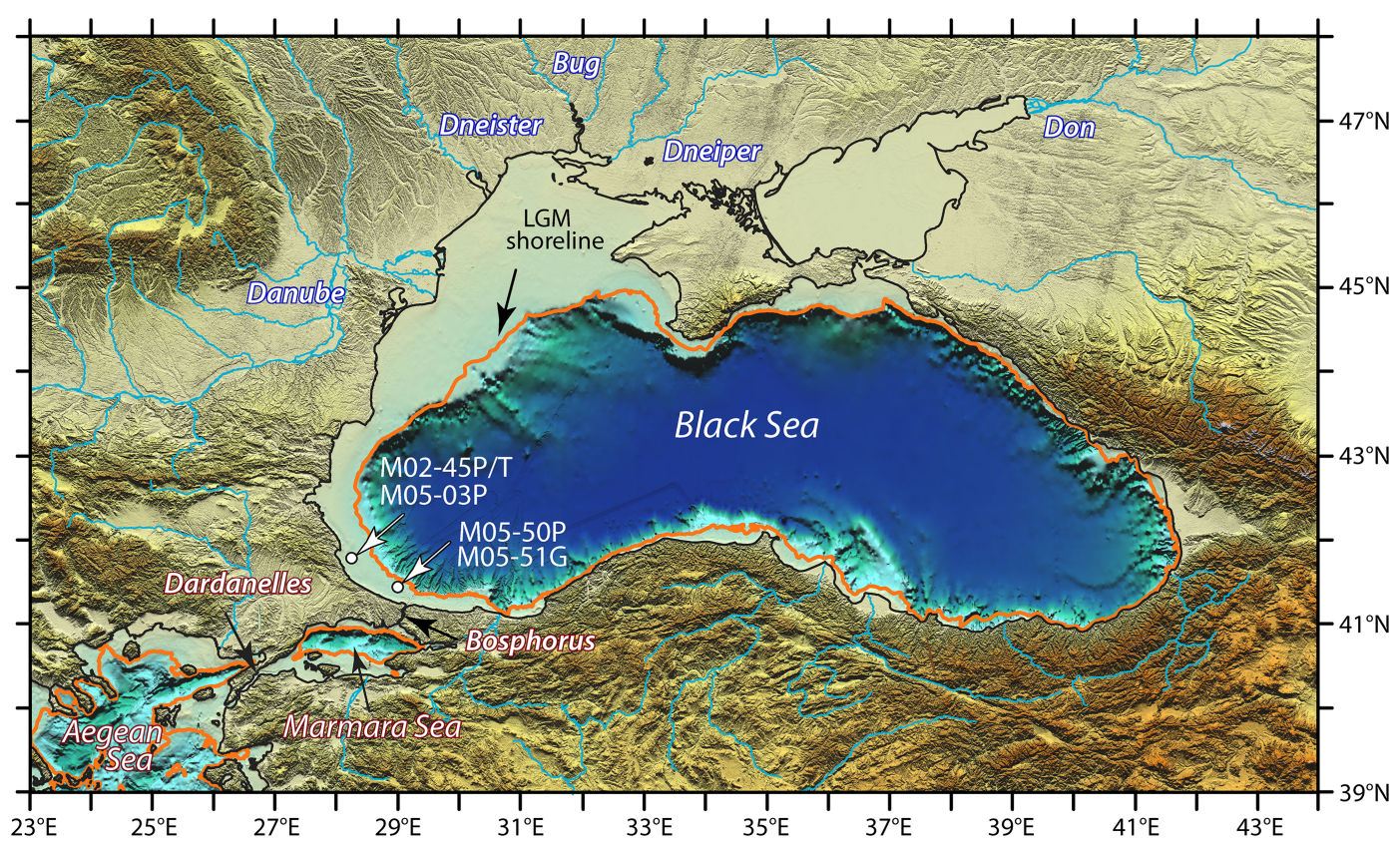

Figure 1 


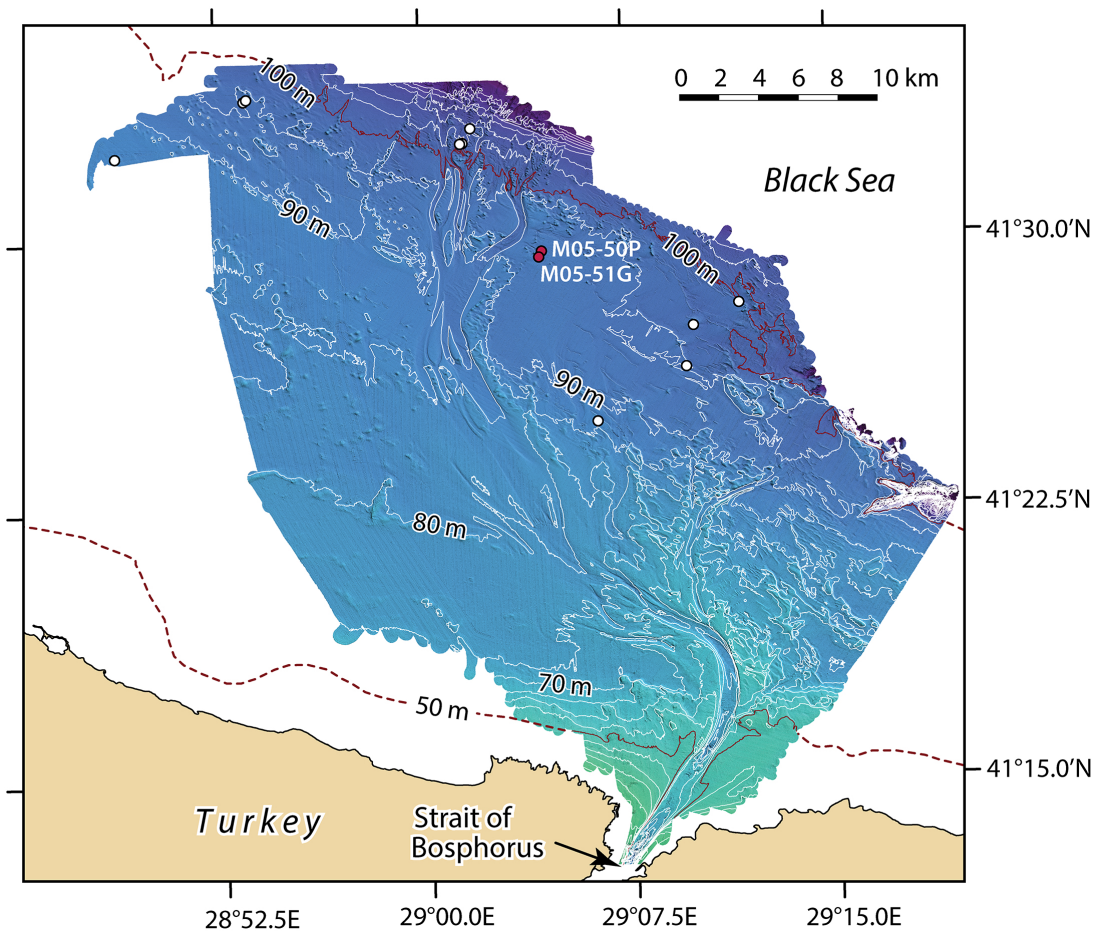

Figure 2 


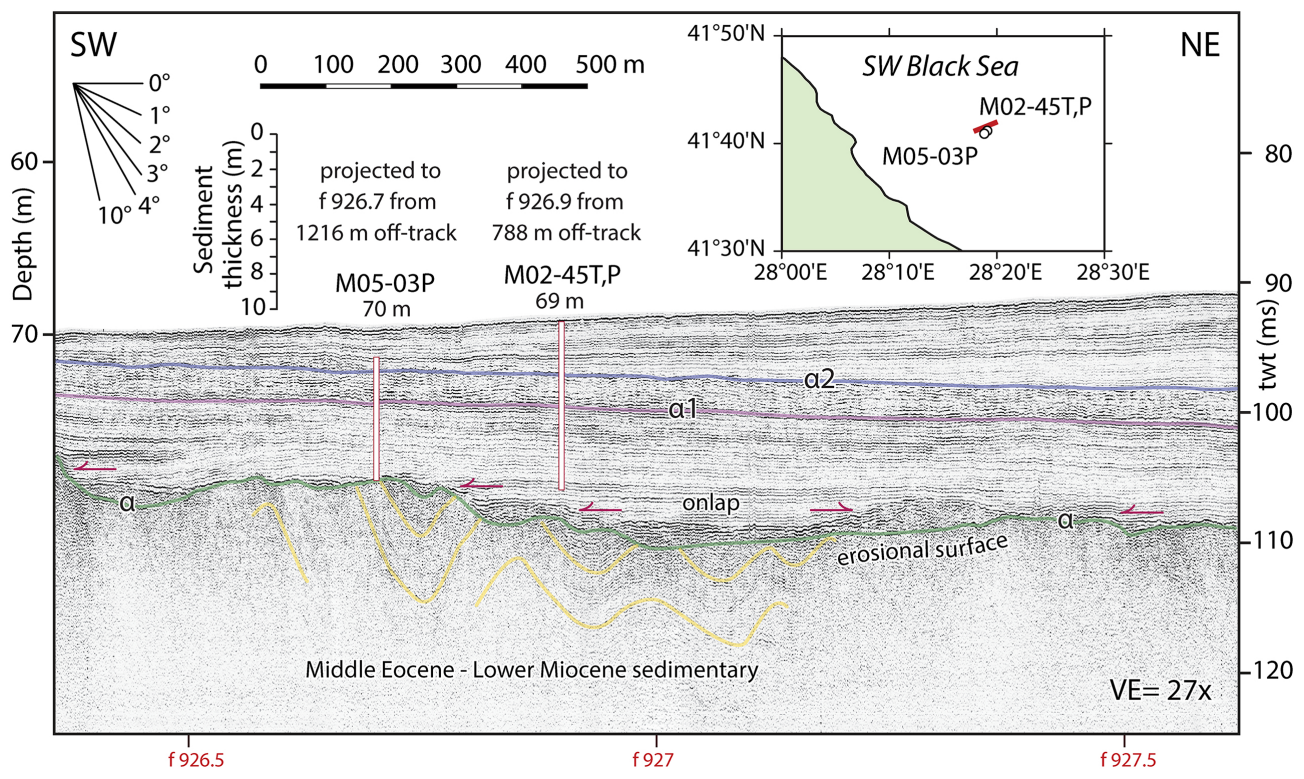

Figure 3 


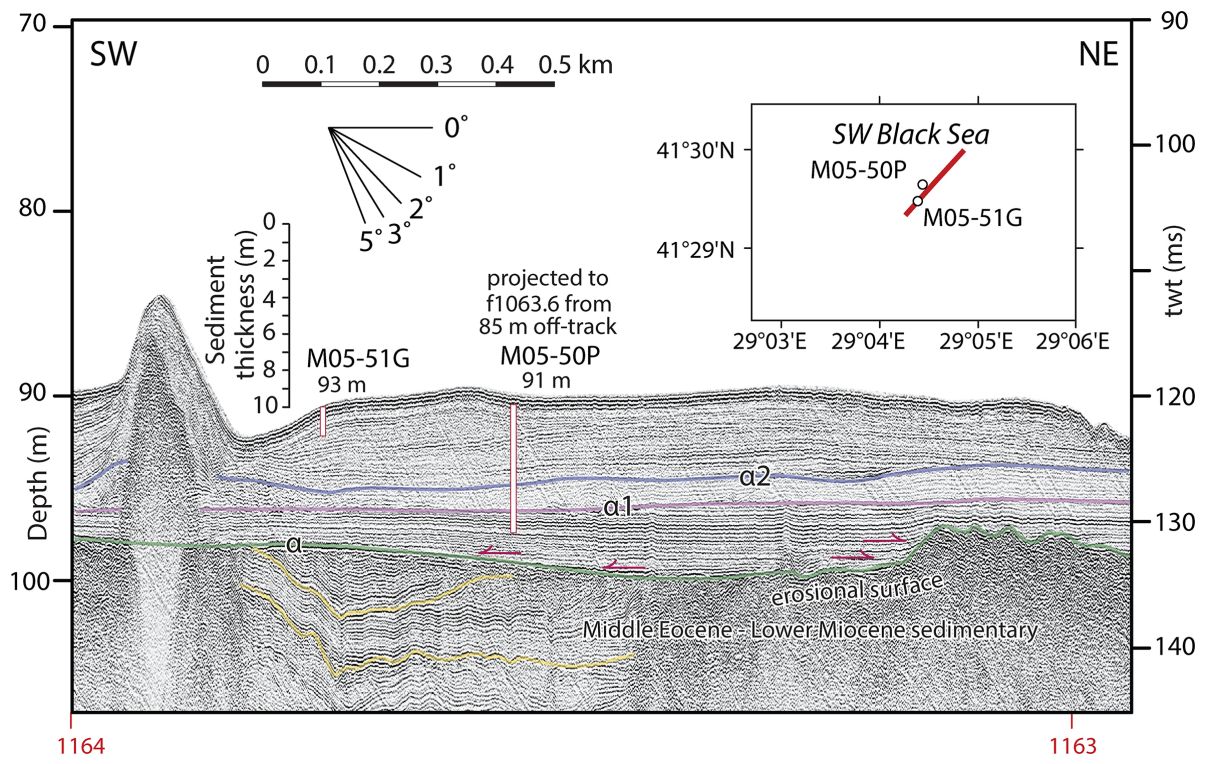

Figure 4 


\section{MAR02-45}

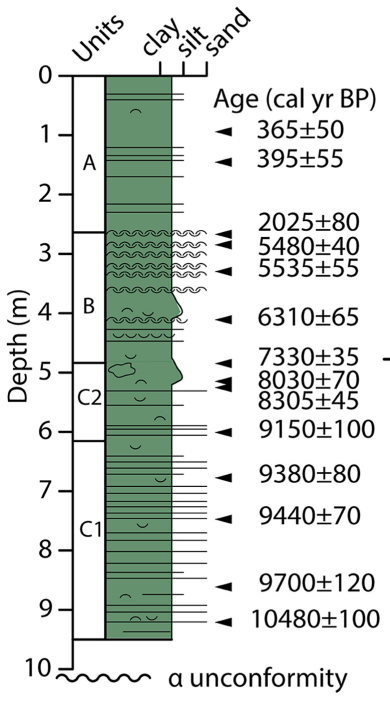

\section{MAR02-45}

Total C (\%)

\section{MAR02-45}

Total S (\%)

\section{MAR02-45}

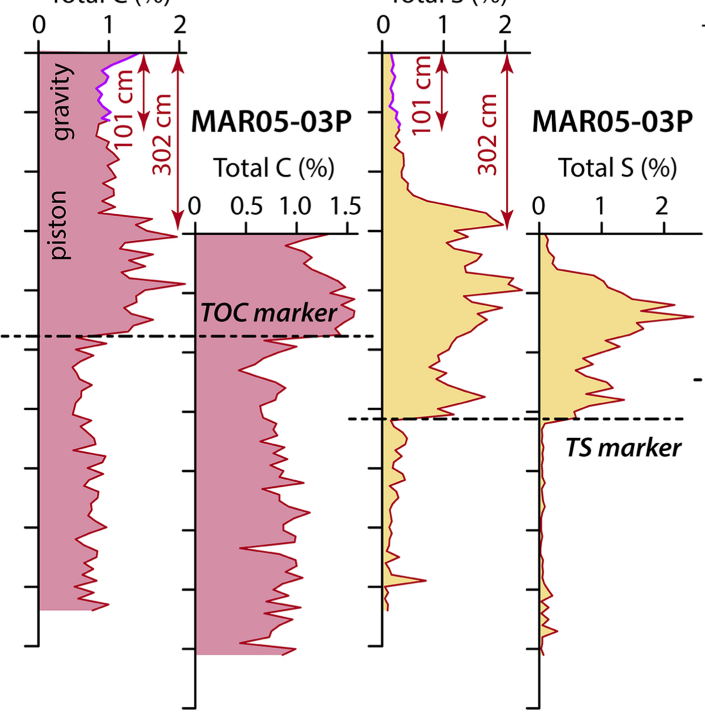

$\delta^{34} S(\%)$

$\begin{array}{r}40 \quad 0 \quad 40 \\ \hline\end{array}$

\section{(1)} бॅ $\varepsilon$ MAR05-03P

$\delta^{34} \mathrm{~S}(\%)$

MAR05-03P

ऽิ

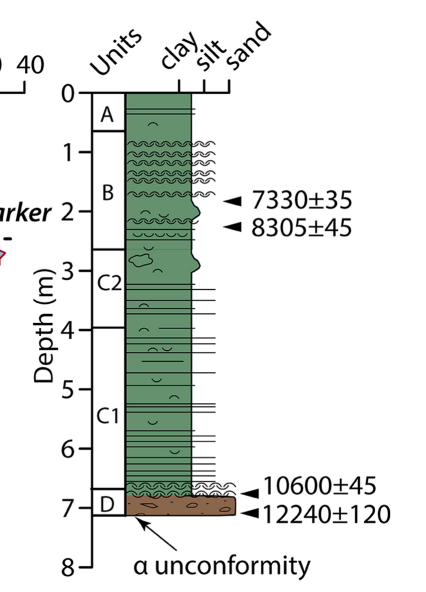

Figure 5 


\section{M02-45 composite}

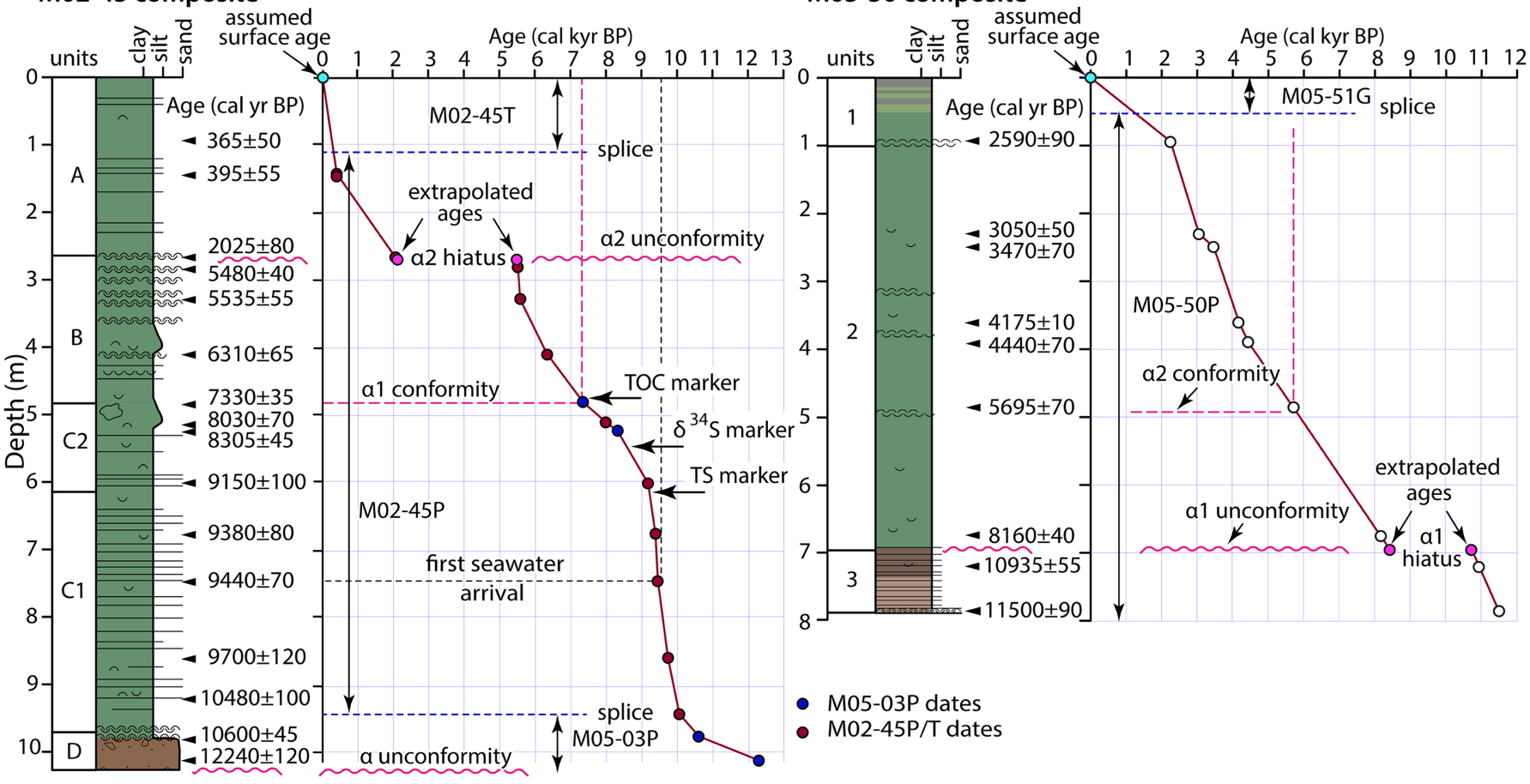




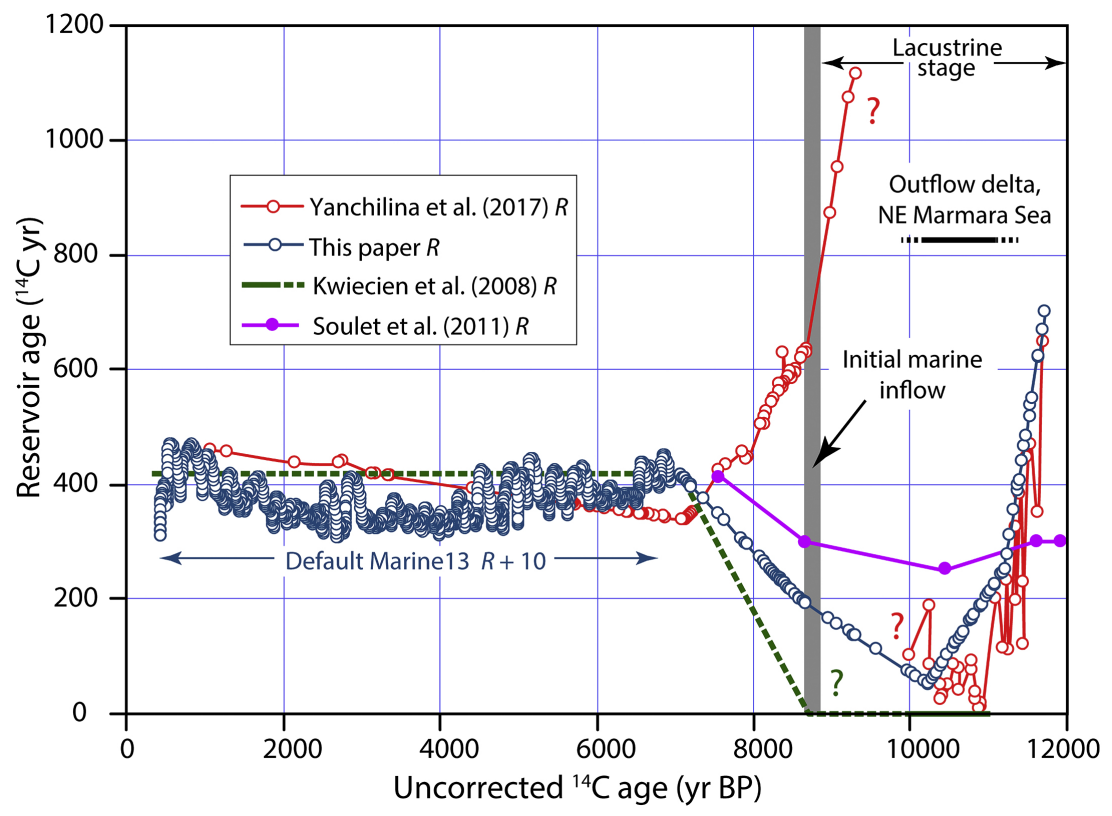

Figure 7 


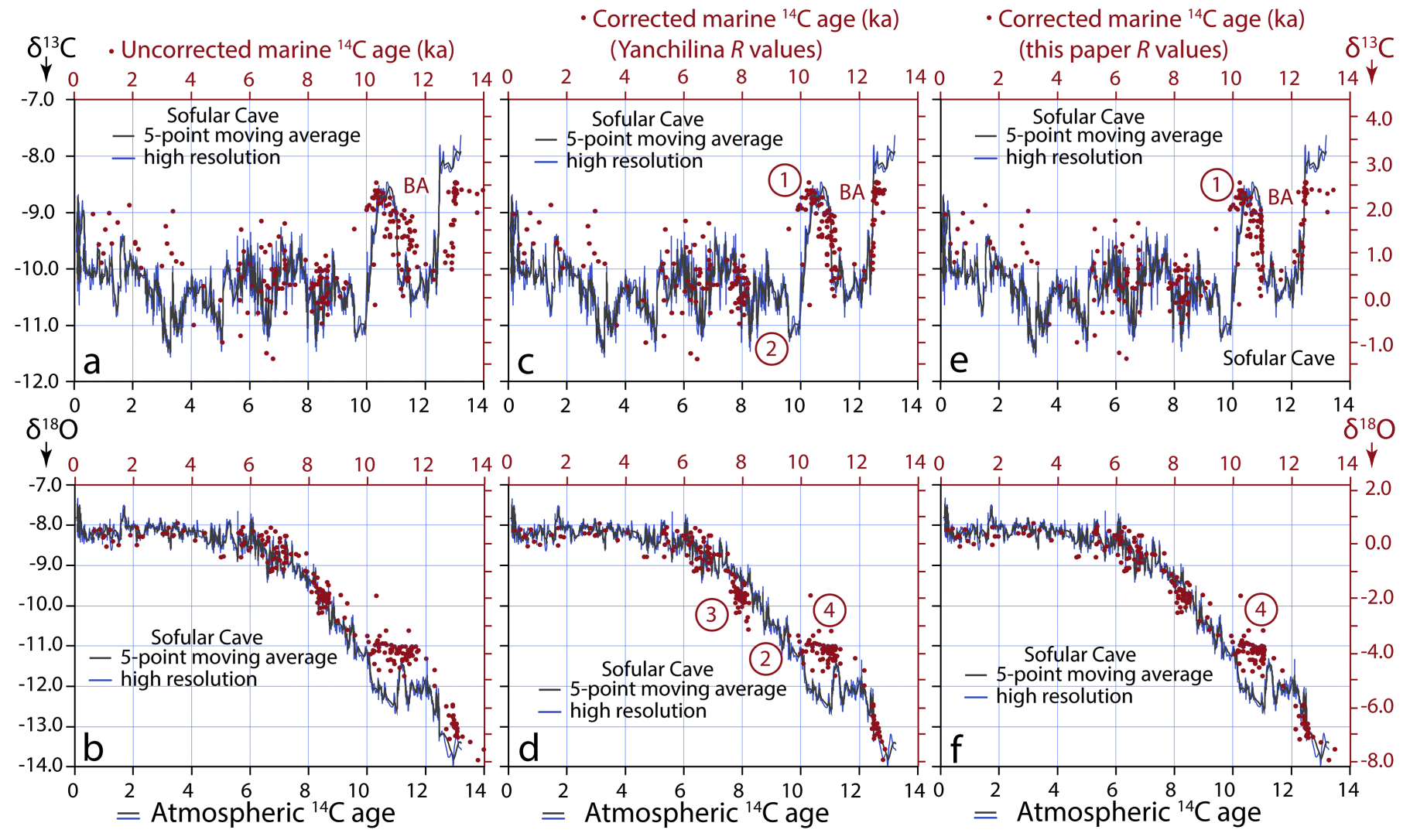






Figure 9 


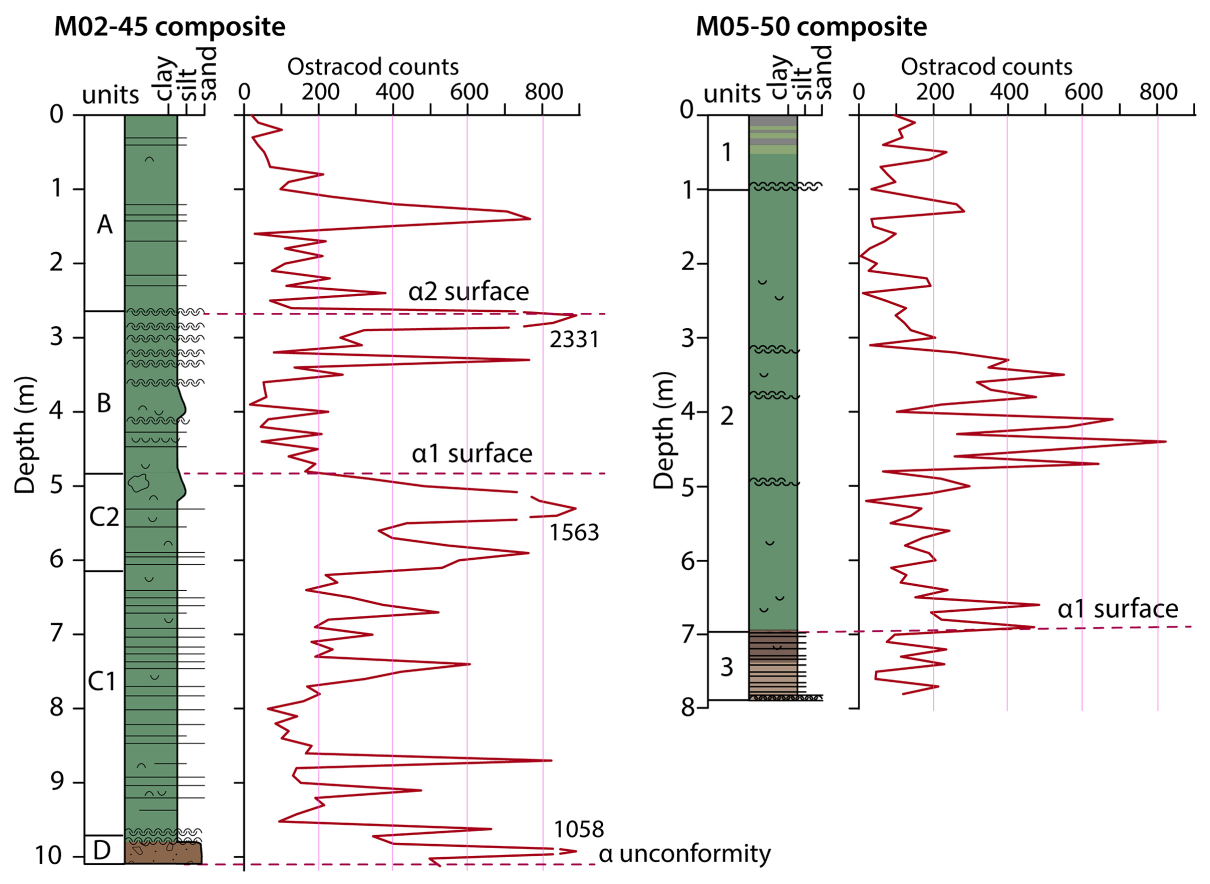

Figure 10 

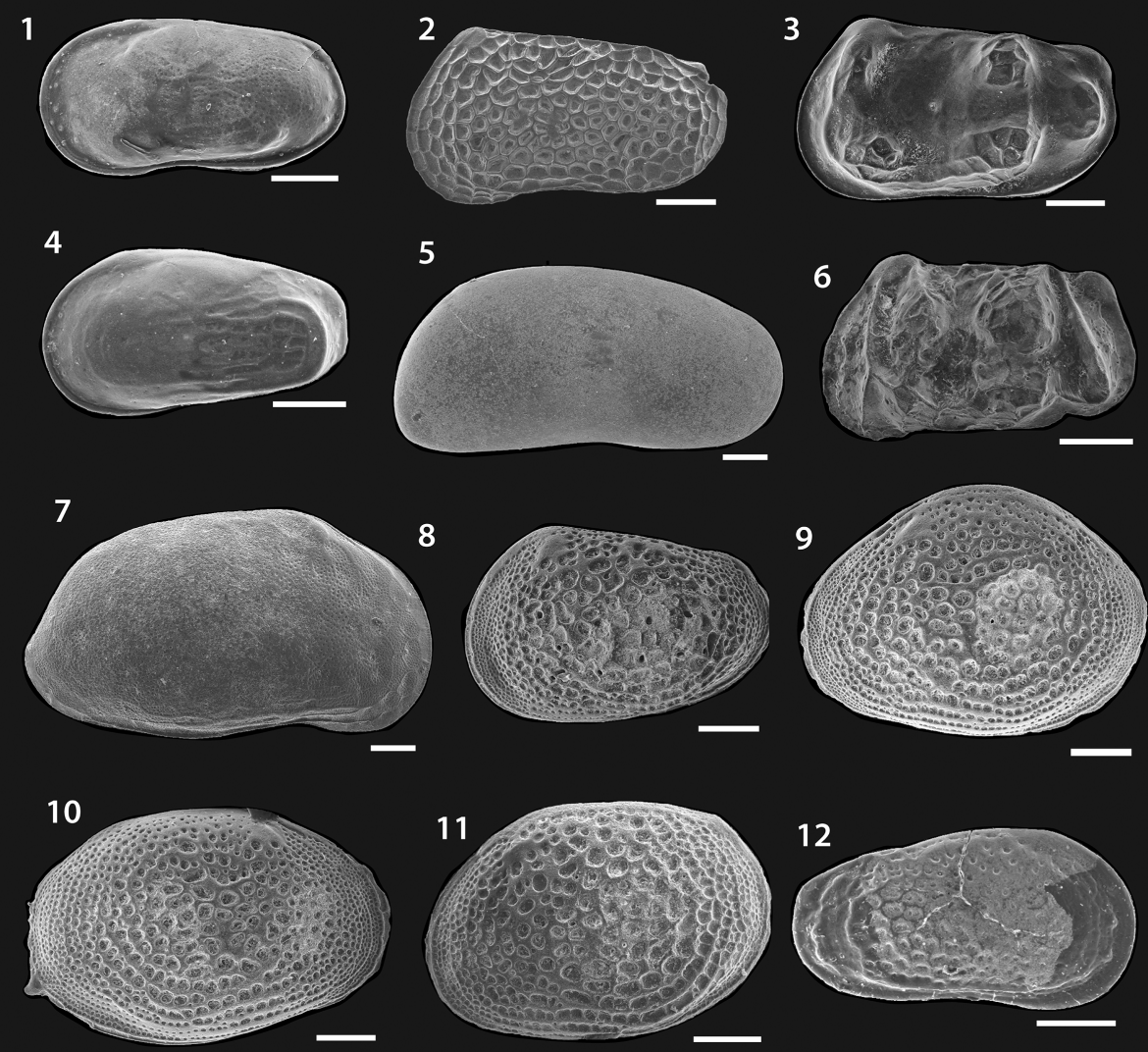

Figure 11 


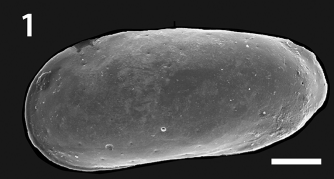

4

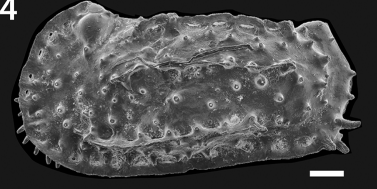

7

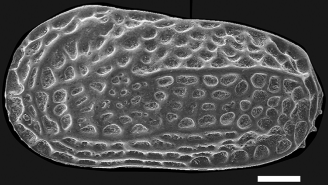

10 and

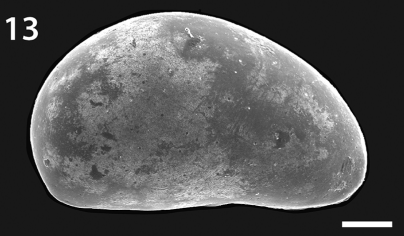

5

11
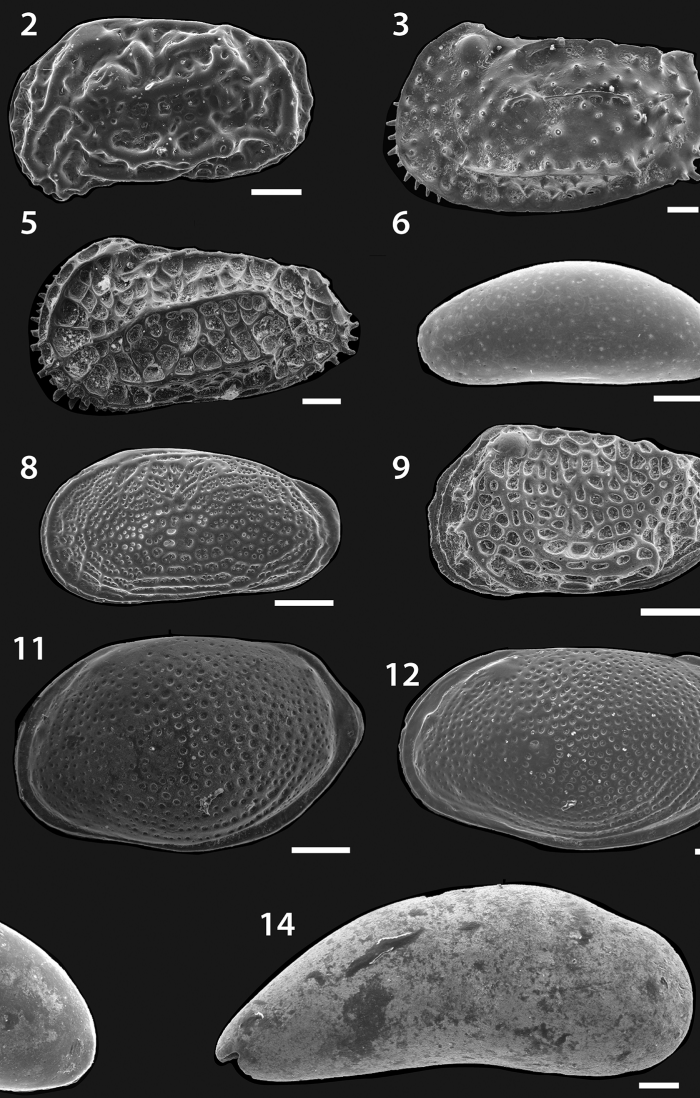

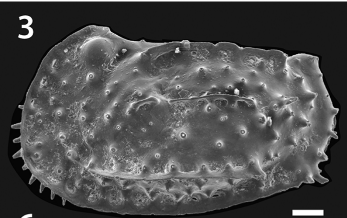

6

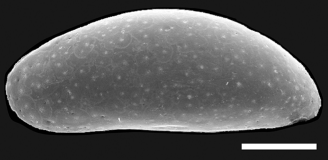

9
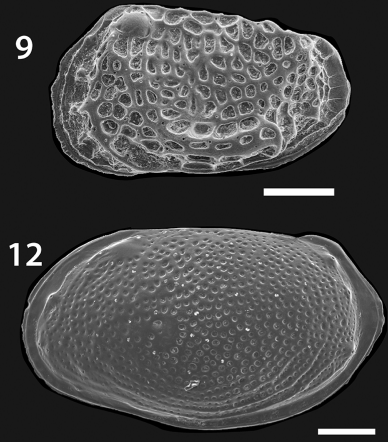

Figure 12 

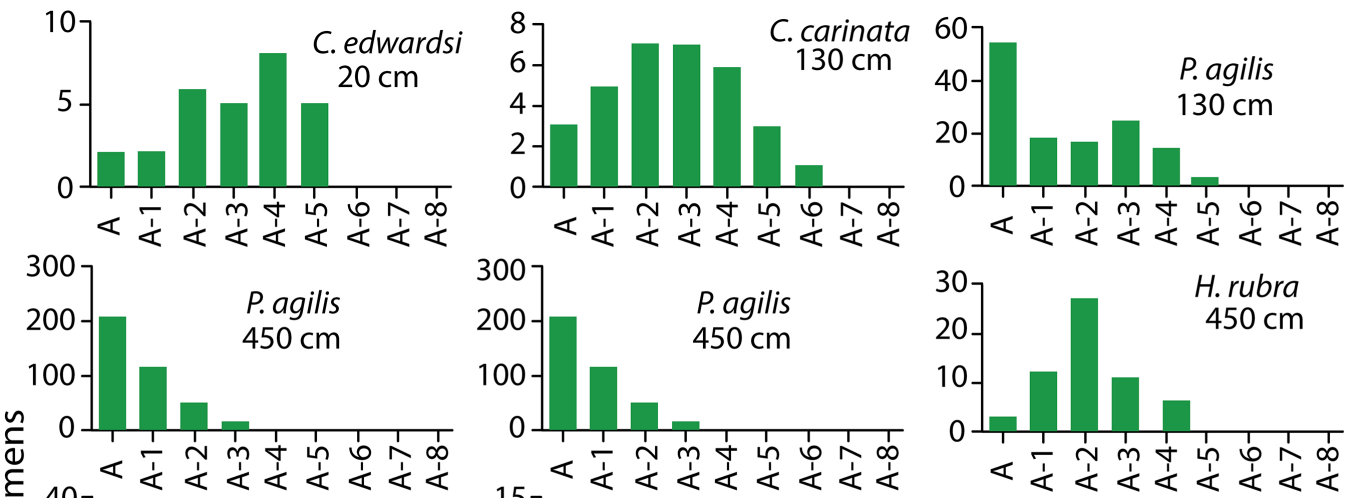

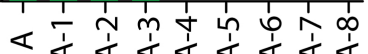
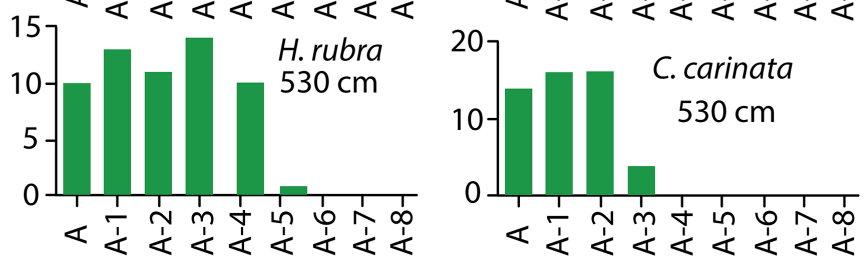

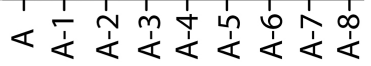
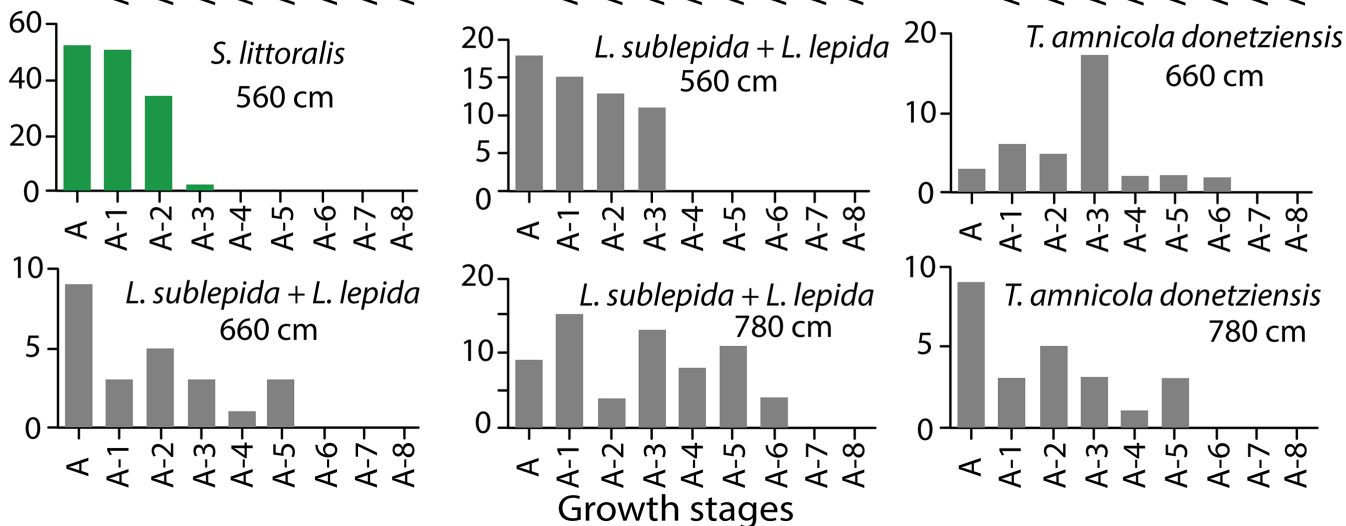

Figure 13 


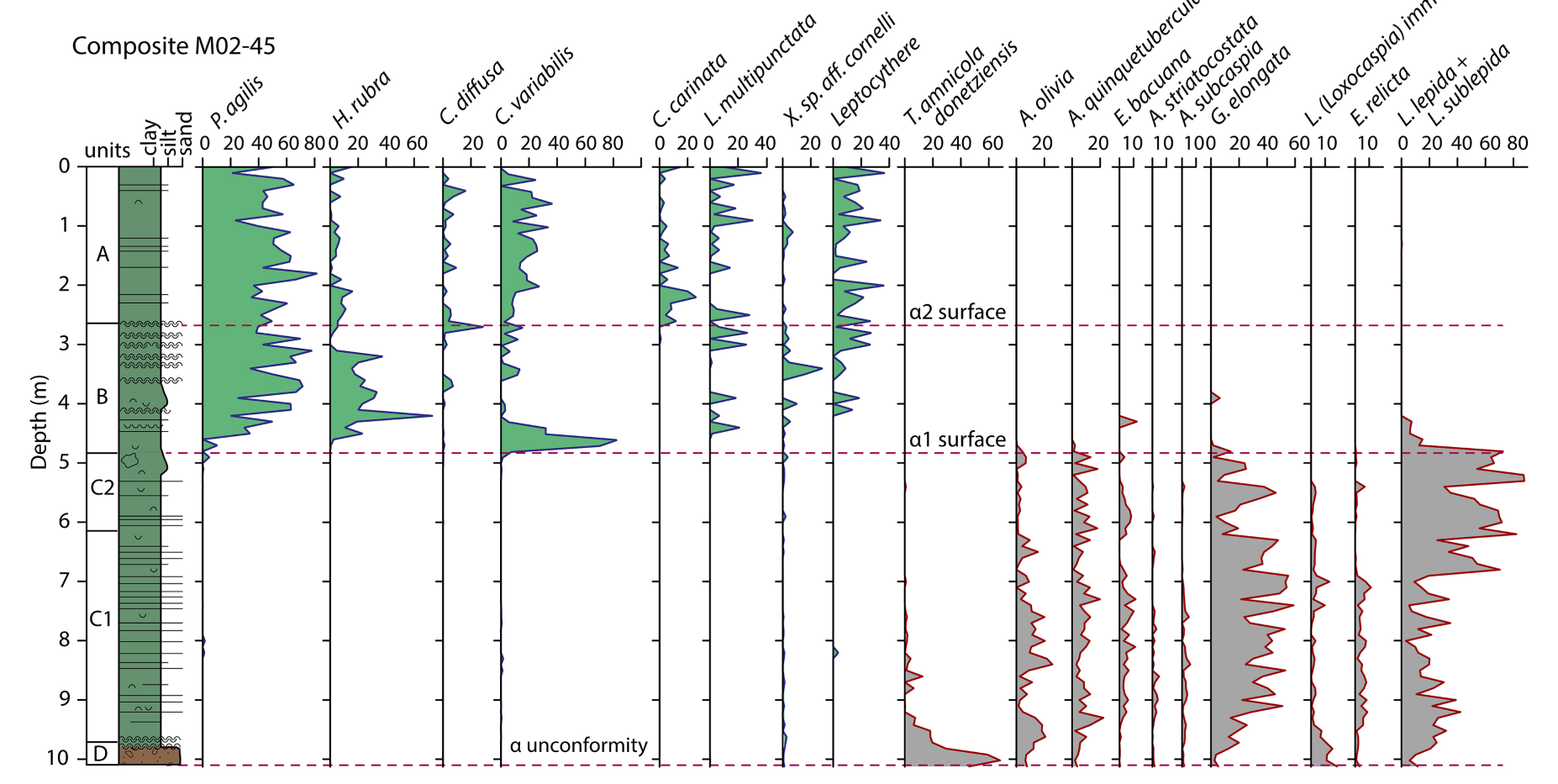


M05-50

$p .09^{0.115}$

4. $4.40^{10}$

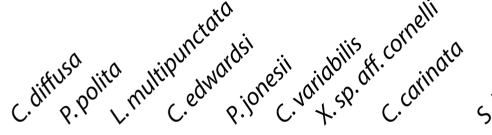

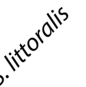

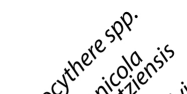

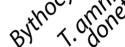

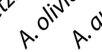

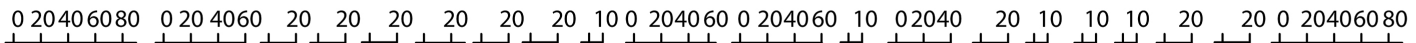

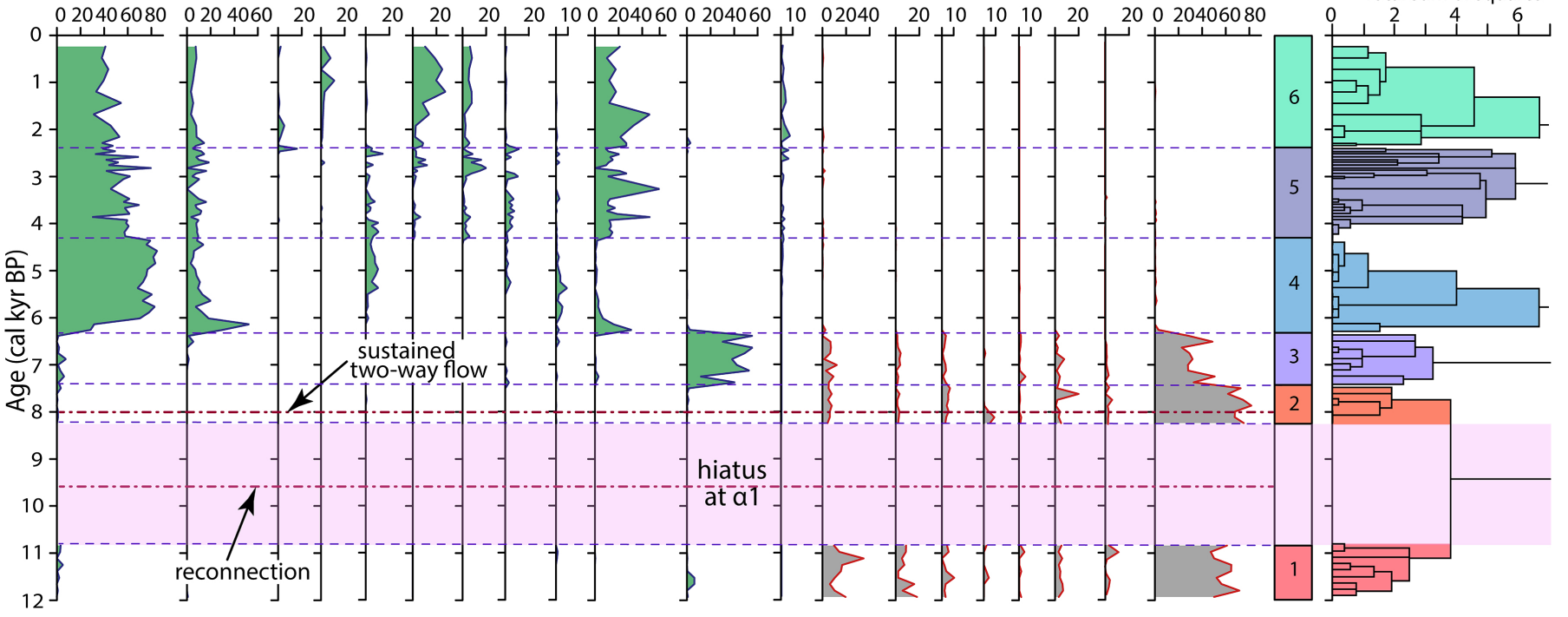




\section{M02-45}

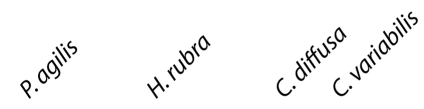
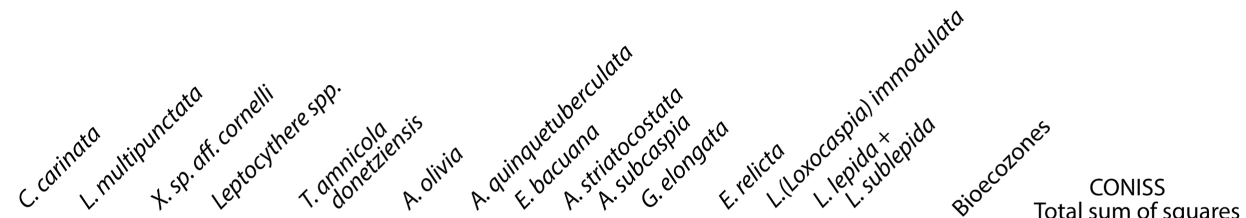

02040608002040608020020406080
2002040020020400204060
202020101002040

2020020406080
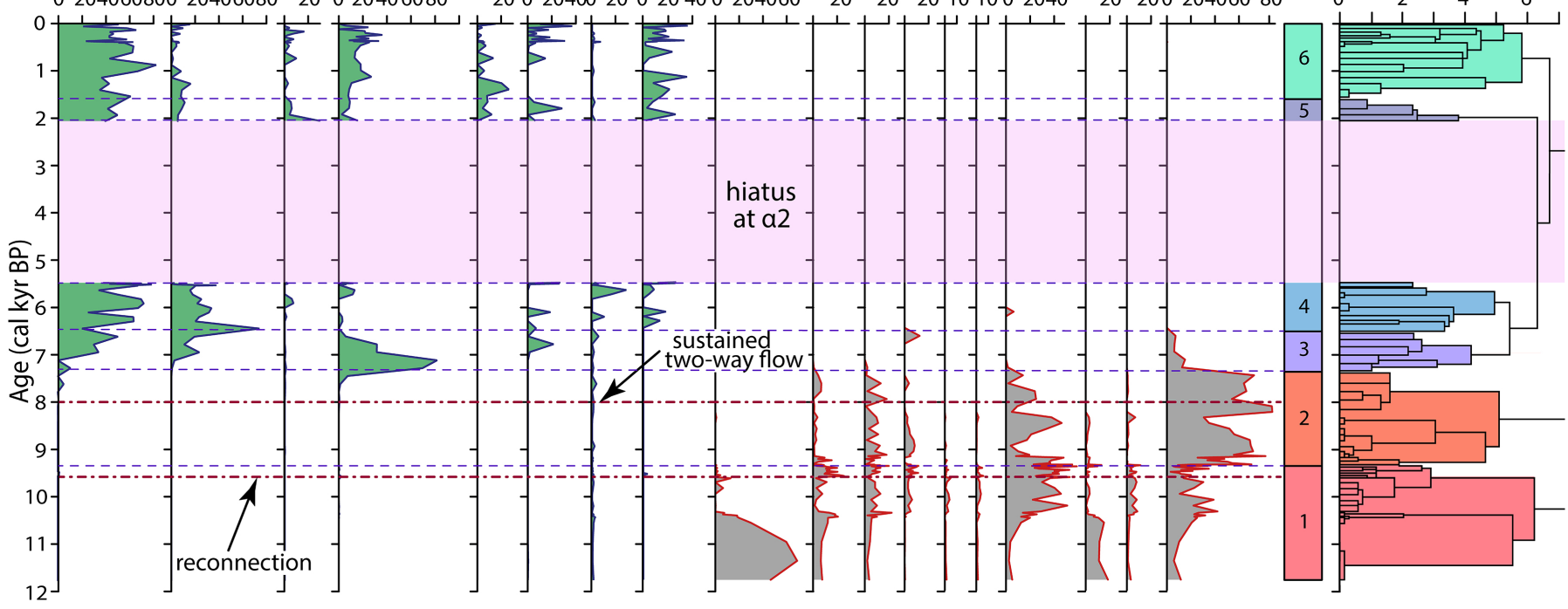

Figure 17 


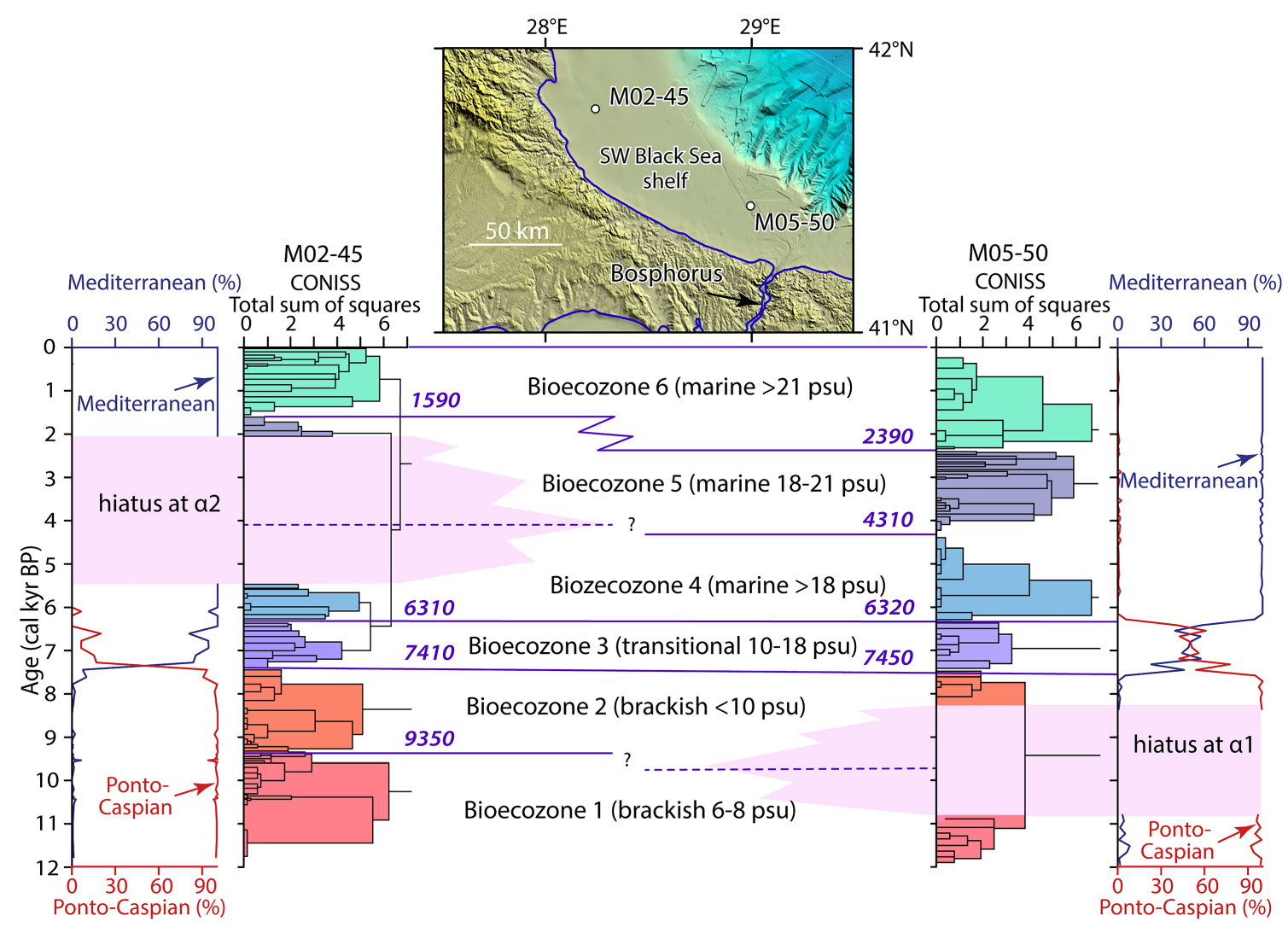

